\title{
A new genus and five new species of Neocoelidiinae leafhoppers from Brazil (Insecta: Hemiptera: Cicadellidae) with a key to males
}

\author{
Clayton C. GONÇALVES ${ }^{\circledR 1}$ \& Alexandre C. DOMAHOVSKI ${ }^{\circledR 2, *}$ \\ ${ }^{1}$ Laboratório de Entomologia, Departamento de Zoologia, Instituto de Biologia, Universidade Federal \\ do Rio de Janeiro. Caixa Postal 68044, 21941-971, Rio de Janeiro, RJ, Brazil. \\ ${ }^{2}$ Departamento de Zoologia, Universidade Federal do Paraná. Caixa Postal 19020, 81531-980, \\ Curitiba, PR, Brazil. \\ "Corresponding author: domahovskiac@yahoo.com.br \\ ${ }^{1}$ Email: clayton.correa.goncalves@gmail.com \\ ${ }^{1}$ urn:1sid:zoobank.org:author:41E6BE64-C8CD-4BAF-86AA-272CF5BE88C5 \\ ${ }^{2}$ urn:1sid:zoobank.org:author:0B988BD5-599B-42CE-ADCB-50FC813E104E
}

\begin{abstract}
A new Brazilian leafhopper genus of the subfamily Neocoelidiinae is proposed: Takiyaella gen. nov. based on T. sexguttata (Chiamolera \& Cavichioli, 2003) gen. et comb. nov. and five new species: T. anomala gen. et sp. nov., T. coelhomarquesae gen. et sp. nov., and T. daniela gen. et sp. nov. from the state of Rio de Janeiro; T. cavichiolii gen. et sp. nov. from the state of Paraná, and T. mejdalanii gen. et sp. nov. from the state of Minas Gerais. A distribution map and identification key to Takiyaella species are provided.
\end{abstract}

Keywords. Auchenorrhyncha, leafhoppers, Neocoelidiini, Neotropical region, taxonomy.

Gonçalves C.C. \& Domahovski A.C. 2021. A new genus and five new species of Neocoelidiinae leafhoppers from Brazil (Insecta: Hemiptera: Cicadellidae) with a key to males. European Journal of Taxonomy 775: 34-61. https://doi.org/10.5852/ejt.2021.775.1545

\section{Introduction}

Neocoelidiinae Oman, 1943 includes leafhoppers restricted to the New World, most of which are endemic to the Neotropical region and only four genera occur in the Nearctic region (Nielson \& Knight 2000). Currently, the subfamily is divided into two tribes: Neocoelidiini Oman, 1943 with 28 genera and 175 species and Krocodonini Marques-Costa \& Cavichioli, 2012 with 14 species allocated in four living genera and one fossil (Dietrich 2003; Marques-Costa \& Cavichioli 2012; Coelho-Marques \& Ale-Rocha 2016, 2017; Gonçalves \& Mejdalani 2017). In the phylogenomics of Membracoidea Rafinesque, 1815 (Dietrich et al. 2017), using 388 loci and more than 99,000 aligned nucleotide positions, Neocoelidiinae was recovered as a sister group of Portanini Linnavuori, 1959 (Aphrodinae), both as a sister group of Deltocephalinae Dallas, 1870. 
Neocoelidiines are small to large leafhoppers, measuring 3-14 $\mathrm{mm}$, commonly having coloration in shades of green, yellow or orange, and are distinguished from other subfamilies by the following combination of characters: (1) crown generally elevated and flat between the eyes; (2) ocelli in the transition between the crown and frons or close to it, rarely located on the crown or face; (3) frons with muscle impressions inconspicuous or slightly visible; (4) very long antenna, often exceeding the total body length; (5) pronotum with posterior margin usually emarginate $V$-shaped; (6) mesothorax frequently well developed, pleurae extending to the sternum, giving individuals a swollen aspect ventrally; (7) forewing with venation usually indistinct, except apically and (8) with transverse vein $r-m_{1}$ absent; (9) hind wing with $\mathrm{R}_{4+5}$ and $\mathrm{M}_{1+2}$ veins usually confluent preapically, fused at the apex, forming a single vein; and (10) valve of the male terminalia generally entirely fused to the subgenital plates (Kramer 1964; Dietrich 2003; Marques-Costa \& Cavichioli 2012).

There are few records regarding the biology and habits of the neocoelidiines. It is known that most species can be found in fields and forested areas, over trees and shrubs. Members of this subfamily were collected on plants of the following genera: Arctostaphylos Adans., Coffea L., Heterotheca Cass., Hordeum L., Ipomoea L., Medicago L., Musa L., Paspalum L., Persea Mill., Pinus L., Pluchea Cass., Prunus L., Pyrus L., Quercus L., Rhus L., Sapindus L., Senegalia Raf., Sphaeralcea A.St.-Hil, and Vigna Savi (Bruner \& Metcalf 1934; Knull 1942; DeLong 1953; Kramer 1967; Maes \& Godoy 1993; Chiamolera \& Cavichioli 2005).

This paper aims to describe a new genus of Neocoelidiini from Brazil: Takiyaella gen. nov. based on T. sexgutatta (Chiamolera \& Cavichioli, 2003) gen. et comb. nov. and five new species: T. anomala gen. et sp. nov., T. coelhomarquesae gen. et sp. nov. and T. daniela gen. et sp. nov. from the state of Rio de Janeiro, T. cavichiolii gen. et sp. nov. from the state of Paraná and T. mejdalanii gen. et sp. nov. from the state of Minas Gerais. A distribution map and key to males of Takiyaella gen. nov. are provided.

\section{Material and methods}

\section{Institutional abbreviations}

DZRJ = Coleção Entomológica Prof. José Alfredo Pinheiro Dutra, Universidade Federal do Rio de Janeiro, Rio de Janeiro, Brazil.

DZUP = Coleção Entomológica Pe. Jesus Santiago Moure, Universidade Federal do Paraná, Curitiba, Brazil.

MNRJ = Departamento de Entomologia, Museu Nacional, Universidade Federal do Rio de Janeiro, Rio de Janeiro, Brazil.

Terminology follows mainly Young $(1968,1977)$, except for head features (Hamilton 1981; Mejdalani 1993, 1998), wings (Dietrich 2005), leg chaetotaxy (Rakitov 1997) and sculpturing pattern of first valvulae of ovipositor (Hill 1970). Techniques used for dissection of the male terminalia follow Oman (1949), with a few modifications described by Cavichioli \& Takiya (2012). Female terminalia were prepared according to the techniques of Zanol (1988) and Mejdalani (1998). Square brackets ([ ]) in material label data were used to supplement abbreviated information. The distribution map was compiled in QGIS® ver. 3.16 (2021; http://www.qgis.org/). 


\title{
Results
}

\section{Taxonomy}

\author{
Class Insecta Linnaeus, 1758 \\ Order Hemiptera Linnaeus, 1758 \\ Suborder Auchenorrhyncha Duméril, 1806 \\ Family Cicadellidae Latreille, 1825 \\ Subfamily Neocoelidiinae Oman, 1943 \\ Tribe Neocoelidiini Oman, 1943 \\ Genus Takiyaella gen. nov. \\ urn:1sid:zoobank.org:act:6E1BFF39-D305-4E7C-982E-D315E686A299
}

Figs 1-13

\section{Type-species}

Takiyaella daniela gen. et sp. nov.

\section{Diagnosis}

Medium-sized leafhoppers (Fig. 12). Head (Figs 1A, 7A, 8A) slightly produced anteriorly, with crown-face transition rounded, without carina; lateral margins of crown, adjacent to eyes, elevated and not carinated. Antennal ledge (Fig. 1B) narrow, slightly prominent and weakly carinated. Forewing (Figs 1D, 7D) with two or three dark maculae on claval commissure; crossvein 's' missing. Male pygofer (Figs 3E, 8E) approximately rectangular, ventral margin with sclerotized subapical serrated tooth; caudal margin usually with ventral rounded lobe. Subgenital plates (Figs 1G, 8G) fused to each other along the basal two-thirds; ventral surface with few apical macrosetae. Connective (Figs 1H, 3H) Y- or V-shaped. Aedeagus (Figs 1J, 7J, 8J) with one or two pairs of atrial processes, gonopore apical. Second valvula of ovipositor (Figs 4G, 9G) fused to each other just near base, dorsal margin with several irregular small teeth.

\section{Etymology}

The generic name Takiyaella (feminine noun) is a tribute to Prof. Dr Daniela Maeda Takiya in recognition of her remarkable contribution to our knowledge of the Brazilian Auchenorrhyncha.

\section{Description}

HEAD AND THORAX. Head, in dorsal view (Figs 1A, 7A), slightly produced anteriorly, median length of crown approximately equal or slightly less than interocular width; transocular width about $4 / 5$ humeral width of pronotum; crown subrectangular, anterior margin rounded, surface flat, texture shagreen; ocellus medium-sized, on anterior margin of head, distant from eye margin, visible in dorsal view; coronal maculae distinct at basal half, between midline and eyes; coronal suture distinct in basal third, evanescent anteriorly. Head, in frontal view (Figs 1B, 10B), with face slightly higher than wide; frontogenal suture extending to antennal ledge but not reaching ocellus; antennal ledge narrow, slightly prominent, oblique and weakly carinated; frons approximately $1.8 \times$ as long as wide; muscle impressions indistinct; epistomal suture distinct but incomplete, evanescent medially; clypeus $1.5 \times$ as long as maximum width, lateral margins parallel, apex slightly emarginated; maxillary plate produced ventrally, reaching clypeus apex; lorum ellipse-shaped, apical margin not reaching apex of clypeus; gena incompletely covering episternum. Head, in lateral view (Figs 1C, 3C), with crown-face transition rounded, without carina; lateral margins of crown, adjacent to eyes, elevated and not carinated; antennal pits at same level as an imaginary line tangent to anteroventral angles of eyes; antenna with long flagellum, exceeding half-length of forewing; frons convex. Pronotum (Figs 1A, 5A) with inconspicuous transverse striae 
on disc; lateral margins rounded, convergent anterad, and slightly shorter than eye length; posterior margin roundly excavated; in lateral view (Figs 1C, 8C), slightly declivous; dorsopleural carina present and complete. Mesonotum (Fig. 8A) as long as wide. Forewing (Figs 1D, 7D) mostly semi-hyaline, except for apical cells and apex of anteapical cells hyaline, $3.5 \times$ as long as maximum width; venation indistinct, except apically; two anteapical cells, crossvein sectorial 's' missing; four apical cells: first to third approximately rectangular, third enlarged apically, fourth rhomboid, base of second more proximal than base of third; appendix narrow; apex rounded. Hind wing with vein $\mathrm{R}_{4+5}$ and $\mathrm{M}_{1+2}$ preapically convergent, fused to each other at apex, forming single vein. Profemur with AD, AM, and PD rows reduced and poorly defined, with exception of apical setae $\mathrm{AD}_{1}, \mathrm{AM}_{1}$, and $\mathrm{PD}_{1}$, respectively; $\mathrm{AV}$ and $\mathrm{PV}$ rows absent; IC row formed by slightly arched comb of fine setae, beginning at distal half of femur and extending to apex. Protibia, in cross-section, semi-circular; AV row formed by approximately 20 setae, slightly longer and thicker towards apex; AD and PD rows without differentiated setae; PV row with 2-3 widely spaced setae. Metafemur with setal formula 2:2:1, with inner setae of second pair reduced in size. Metatibial AD row with 2-4 intercalary setae between macrosetae; PD, AD, and PV rows with 13$15,10-12$, and 28-32 macrosetae, respectively; AV row with approximately 11 macrosetae distributed along most of tibia, except in the proximal and distal portions. Metatarsomere I longer than combined length of two distal tarsomeres; plantar surface with two rows of setae, external row with longer and robust setae than inner row; pecten with five platellae. Metatarsomere II pecten with three platellae.

Male terminalia. Pygofer (Figs 1E, 3E, 5E) approximately rectangular, usually apically expanded with an apical ventral lobe; macrosetae absent; ventral margin little sclerotized medially, with a sclerotized and serrated tooth on apical portion. Valve (Figs $1 \mathrm{G}, 8 \mathrm{G}$ ) without indication of separation with subgenital plates. Subgenital plate (Figs 3G, 5G) not exceeding pygofer apex; plates fused to each other along the basal two-thirds; ventral surface with few apical macrosetae; in lateral view (Figs 1F, 7F), deeply concave. Connective (Figs 1H, 7H) Y- or V-shaped, articulated to aedeagus base, not bifurcated at the point of articulation. Style (Figs 1I, 8I) with apodeme expanded; ventral margin with median lobe; preapical setae present; preapical lobe moderately developed, slightly produced posterad; apex curved ventrally, hook-shaped. Aedeagus (Figs $1 \mathrm{~J}-\mathrm{K}, 5 \mathrm{~J}-\mathrm{K}$ ) with preatrium long and robust; atrium with one or two pairs of processes; shaft curved dorsoanteriorly, usually expanded at apex; gonopore apical. Anal tube (Figs 3M, 5L, 8E) cylindrical, usually with small basiventral process with denticles.

Female terminalia. Sternite VII (Figs 2C, 4C, 6C, 9C, 11A) subquadrangular; posterior margin widely rounded. 'Internal' sternite VIII membranous. Pygofer (Figs 2D, 4D, 6D, 9D, 11B) elongate, $1.7 \times$ as long as maximum height; macrosetae distributed near apex and ventral margin. First valvifer (Figs 2E, 4E, 6E, 9E, 11C) higher than long, dorsal margin straight, posterior margin slightly oblique. First valvula of ovipositor (Figs 2E, 4E, 6E, 9E, 11C) elongated, moderately curved dorsally; dorsal sculptured area submarginal, present throughout apical half; apex (Figs 2F, 4F, 6F, 9F, 11D) acute. Second valvifer (Figs 2I, 4I, 6I, 9I, 11G) higher than long. Second valvula of ovipositor (Figs 2G, 4G, 6G, 9G, 11E) elongated, moderately curved dorsally in the apical half, fused to each other just near base; apical portion (Figs $2 \mathrm{H}, 4 \mathrm{H}, 6 \mathrm{H}, 9 \mathrm{H}, 11 \mathrm{~F}$ ) slightly expanded, dorsal margin with several irregular small teeth. Gonoplac (Figs 2I, 4I, 6I, 9I, 11G) expanded on apical half; external surface along ventral margin and apex with dentiform cuticular projections and few short and robust setae; apex (Figs 2J, 4J, 6J, 9J, 11H) rounded or acutely rounded.

\section{Distribution}

Brazil (states of Minas Gerais, Paraná and Rio de Janeiro). Species of Takiyaella gen. nov. occur in southern and southeastern Brazil, in the Atlantic Rainforest biome (Fig. 13). 


\section{Remarks}

Takiyaella gen. nov. shares some similarities with Paraphysiana Chiamolera, Cavichioli \& Anderle, 2003 as follows: (1) crown with anterior margin rounded; (2) crown-face transition without carina; (3) frontogenal suture not reaching ocellus; (4) antennal ledge narrow and slightly prominent; (5) pronotum with posterior margin roundly excavated; and (6) forewing with dark maculae along the anal margin.

However, the new genus can be easily separated from Paraphysiana due to hind wing with veins $\mathrm{R}_{4+5}$ and $\mathrm{M}_{1+2}$ preapically convergent, fused at apex, forming single vein, whereas in Paraphysiana $\mathrm{R}_{4+5}$ and $\mathrm{M}_{1+2}$ are convergent, fused to each other, but they are divergent apically; pygofer without inner ventral processes (present in Paraphysiana); subgenital plates without dorsal tooth (present in Paraphysiana); style with preapical lobe moderately developed, whereas in Paraphysiana it is strongly developed and produced caudally; paraphysis absent (present in Paraphysiana); and the aedeagus with atrial processes (absent in Paraphysiana).

Takiyaella anomala gen. et sp. nov. urn:lsid:zoobank.org:act:3E2E98B6-FDAE-4452-A5E2-18957D9B57A0

Figs $1-2,12 \mathrm{~A}-\mathrm{B}, 13$

\section{Diagnosis}

Forewing (Fig. 1D) with three dark maculae, two on clavus and one on fourth apical cell. Male pygofer (Fig. 1E) rectangular, not expanded apically. Connective (Fig. 1H) Y-shaped. Aedeagus (Fig. 1J-K) with atrial processes slender, directed posterad, with three spiniform projections; shaft flattened laterally, not expanded apically.

\section{Etymology}

The specific epithet alludes to the singular set of morphological characteristics of this species.

\section{Material examined}

\section{Holotype}

BRAZIL • ${ }^{\top}$; Rio de Janeiro, Cachoeiras de Macacu, REGUA [Reserva Ecológica de Guapiaçu], ponto

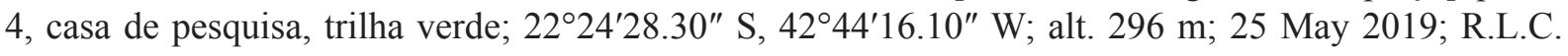
Baptista leg.; coleta visual alta diurna [daytime high visual collection]; DZRJ-AUCH \#238; DZRJ.

\section{Paratypes}

BRAZIL - Rio de Janeiro 1 Oे, 1 \%; Itatiaia, PNI [Parque Nacional de Itatiaia], Lago Azul, mata, PNI-M3B; 2227'1.10" S, 4436'55.30" W; alt. 830 m; 1-3 Dec. 2015; Biota FAPERJ leg.; Malaise trap; MNRJ • 1 \%; same collection data as for preceding; DZUP-083604; DZUP.

\section{Description}

Measurements (mm). Holotype (đ): total length 6.2. Paratypes ( $\overbrace{}^{\Uparrow}): 6.1(\mathrm{n}=1) ;($ ) $) 6.7-6.8(\mathrm{n}=2)$.

Coloration. Pale yellow (Fig. 12A-B). Forewing (Fig. 1D) yellow, translucent, with three dark maculae: first on claval comissure between anal veins, second on apex of clavus and extending to brachial cell, and third on fourth apical cell.

HEAD AND THORAX. External morphological characters as in generic description.

Male terminalia. Pygofer, in lateral view (Fig. 1E), $1.6 \times$ as long as maximum height, not expanded apically, basal portion slightly higher than apical portion; dorsal margin slightly convex; ventral tooth 

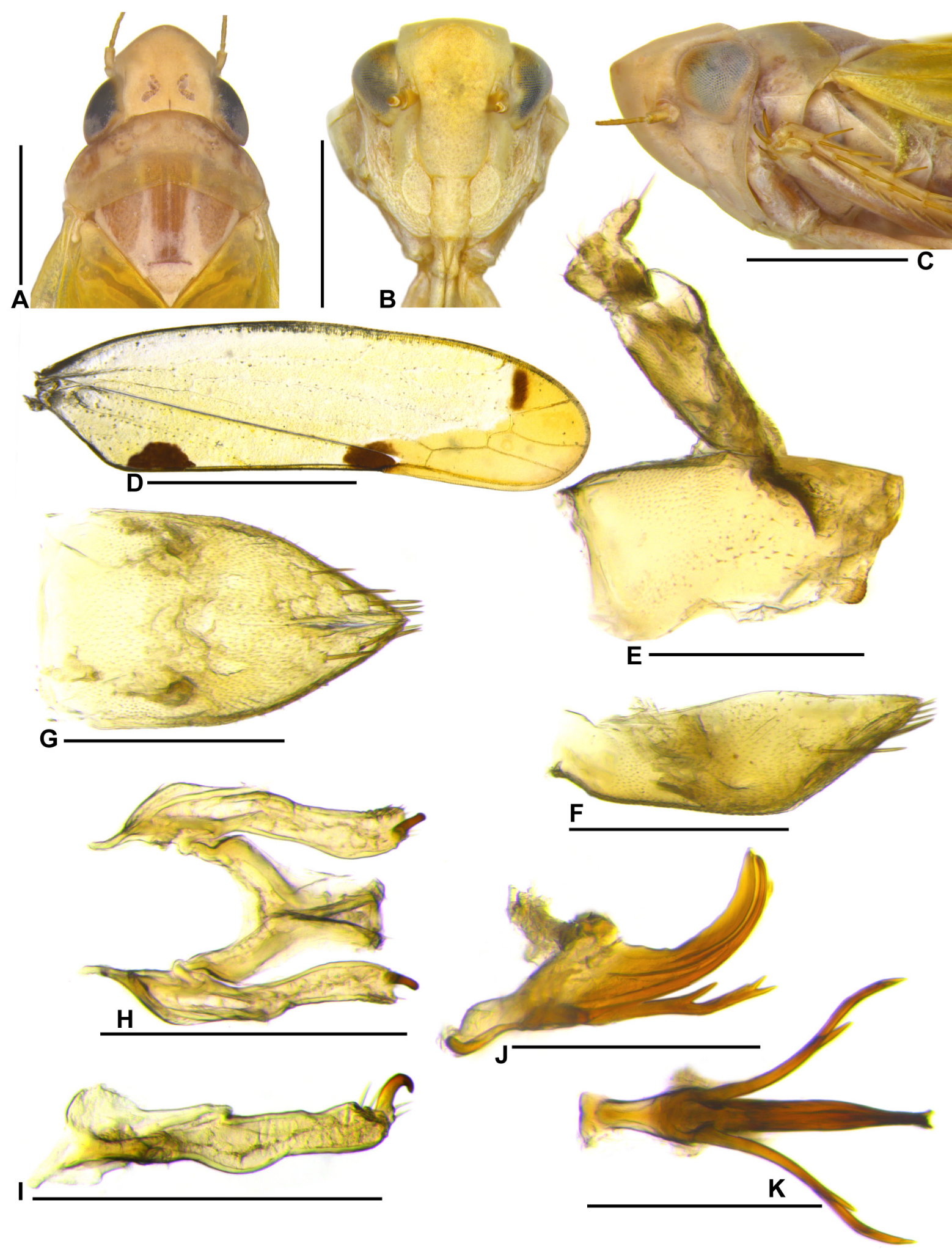

Fig. 1. Takiyaella anomala gen. et sp. nov., Ô, holotype (DZRJ-AUCH \#238). A. Head and thorax, dorsal view. B. Head, frontal view. C. Head and thorax, lateral view. D. Forewing. E. Pygofer and anal tube, lateral view. F. Valve and subgenital plate, lateral view. G. Valve and subgenital plate, ventral view. H. Styles and connective, dorsal view. I. Style, lateral view. J. Aedeagus, lateral view. K. Aedeagus, ventral view. Scale bars: $\mathrm{A}-\mathrm{C}=1.0 \mathrm{~mm} ; \mathrm{D}=2.0 \mathrm{~mm} ; \mathrm{E}-\mathrm{I}=0.5 \mathrm{~mm}$; $-\mathrm{K}=0.4 \mathrm{~mm}$. 


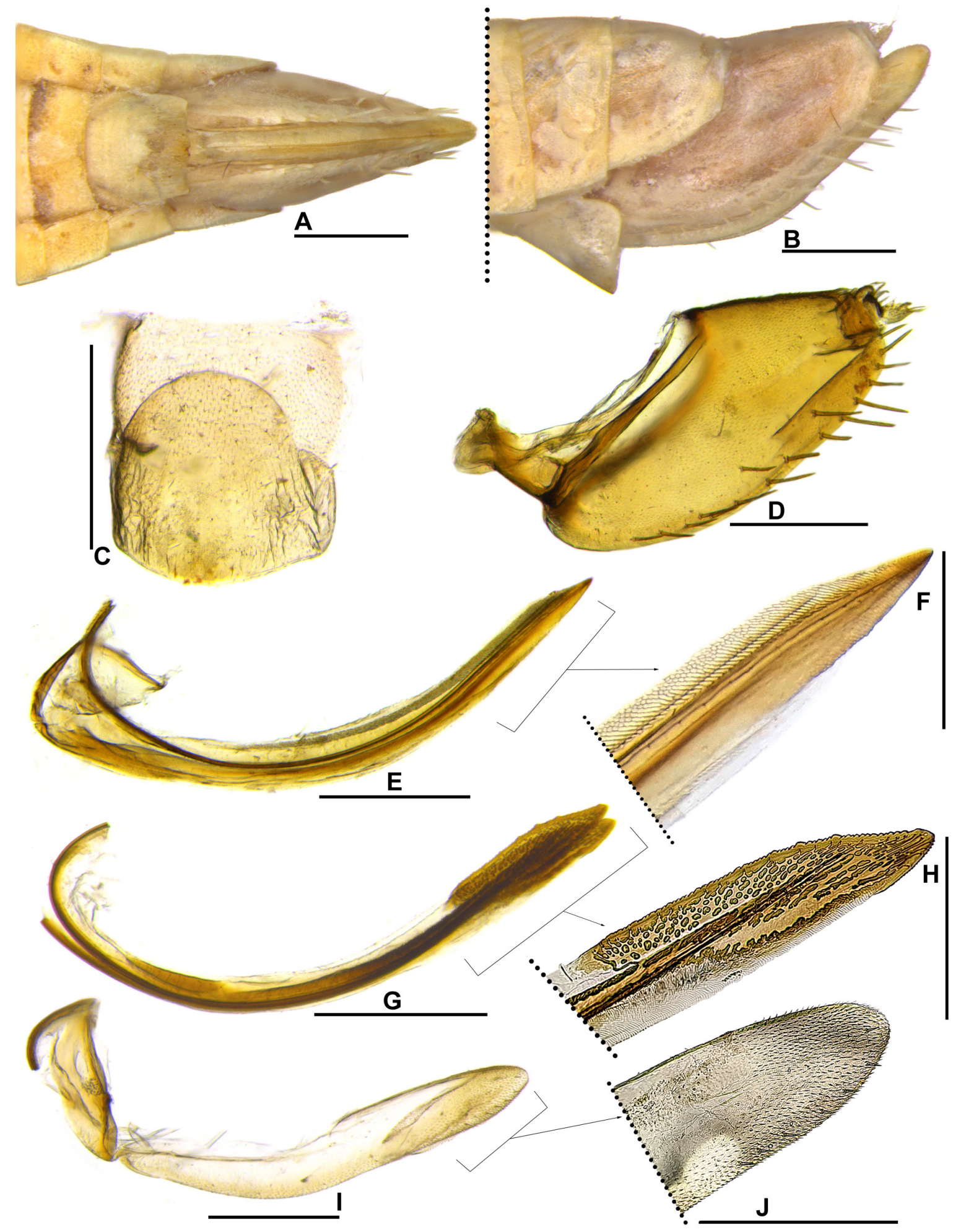

Fig. 2. Takiyaella anomala gen. et sp. nov., +, paratype (MNRJ). A. Posterior portion of abdomen, ventral view. B. Posterior portion of abdomen, lateral view. C. Sternite VII, ventral view. D. Pygofer and anal tube, lateral view. E. First valvifer and first valvula of ovipositor, lateral view. F. Apex of first valvula, lateral view. G. Second valvula of ovipositor, lateral view. H. Apex of second valvula, lateral view. I. Second valvifer and gonoplac, lateral view. J. Apex of gonoplac, lateral view. Scale bars: $\mathrm{A}-\mathrm{B}=1.0 \mathrm{~mm}$; C-E, G, I $=0.5 \mathrm{~mm} ; \mathrm{F}, \mathrm{H}, \mathrm{J}=0.3 \mathrm{~mm}$. 
prominent and rounded; caudal margin truncated; few small setae scattered on middle third. Subgenital plate, in lateral view (Fig. 1F), $2.9 \times$ as long as maximum height, expanded medially; dorsal margin slightly convex; ventral margin oblique in the apical half; apical third strongly narrowed; in ventral view (Fig. 1G), subtriangular, lateral margins parallel on basal half and strongly converging on apical half; ventral surface with pair of uniseriate rows of 5-6 macrosetae; apex acute. Connective (Fig. 1H) Y-shaped, total length about $3 / 5$ length of style; stem approximately as long as arms. Style (Fig. $1 \mathrm{H}-$ I) with dorsal margin of apodeme broadly rounded, ventral margin acutely produced anteroventrally; apophysis elongated, robust. Aedeagus (Fig. 1J-K) with pair of slender atrial processes, each process with approximately half length of shaft, directed posterad and strongly divergent in ventral view, apical third with three spiniform projections, one longer on dorsal margin, and two smaller on apex; shaft flattened laterally, curved dorsally at basal third, with pair of small subapical ventral lamellae. Anal tube (Fig. 1E) with sternite $\mathrm{X}$ long and tubular, without basiventral process.

Female terminalia. Sternite VII (Fig. 2A-C) $1.2 \times$ as long as wide; lateral margins parallel; posterior margin widely rounded. First valvula of ovipositor (Fig. 2F) with dorsal sculptured area areolate-strigate. Other characters as in generic description.

\section{Remarks}

Takiyaella anomala gen. et sp. nov. is the species that most differs from the other species of the genus, being the only one to have the forewing with a dark-brown macula in the fourth apical cell (Fig. 1D); male pygofer, in lateral view, not expanded apically, caudal margin without ventral lobe (Fig. 1E); connective Y-shaped (Fig. 1H); and aedeagus with shaft laterally compressed and not expanded apically (Fig. 1J-K).

Takiyaella cavichiolii gen. et sp. nov. urn:1sid:zoobank.org:act:0E144EA1-5D79-44F8-8042-E34B81111F8D

Figs 3-4, 12C-D, 13

\section{Diagnosis}

Male pygofer (Fig. 3E) expanded apically, with two lobes, dorsal lobe larger and subtriagular, apical lobe smaller and rounded. Aedeagus (Fig. 3J-L) with atrial processes slender, parallel and following the curvature of shaft, apex acute; shaft expanded apically, spatulate, with lateral small spiniform projections. Anal tube (Fig. 3M) with triangular basiventral process.

\section{Etymology}

The specific epithet is a tribute to Prof. Dr Rodney Ramiro Cavichioli in recognition of his remarkable contribution to our knowledge of the Brazilian Auchenorrhyncha.

\section{Material examined}

\section{Holotype}

BRAZIL • đ̃; PR [Paraná], S. J. [São José] dos Pinhais, Rep. [Represa] Guaricana; $25.7176^{\circ}$ S, 48.9640 W; alt. 760 m; 9 Jan.-1 Feb. 2018; Muniz, Melo, Cavichioli and Domahovski leg.; Malaise trap; DZUP 492451; DZUP.

\section{Paratypes}

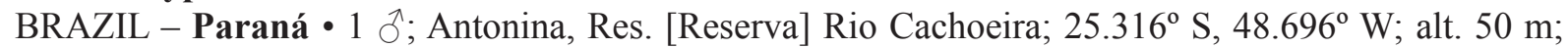
23-27 Jan. 2017; A.C. Domahovski leg.; luz solo [ground light]; DZUP 492472; DZUP • 1 क; same collection data as for preceding; DZUP 492471; DZRJ • 1 \%; same collection data as for preceding; DZUP 492473; DZUP • 1 क ; Antonina, RPPN [Reserva Particular do Patrimônio Natural] Guaricica; $25.316^{\circ}$ S, 

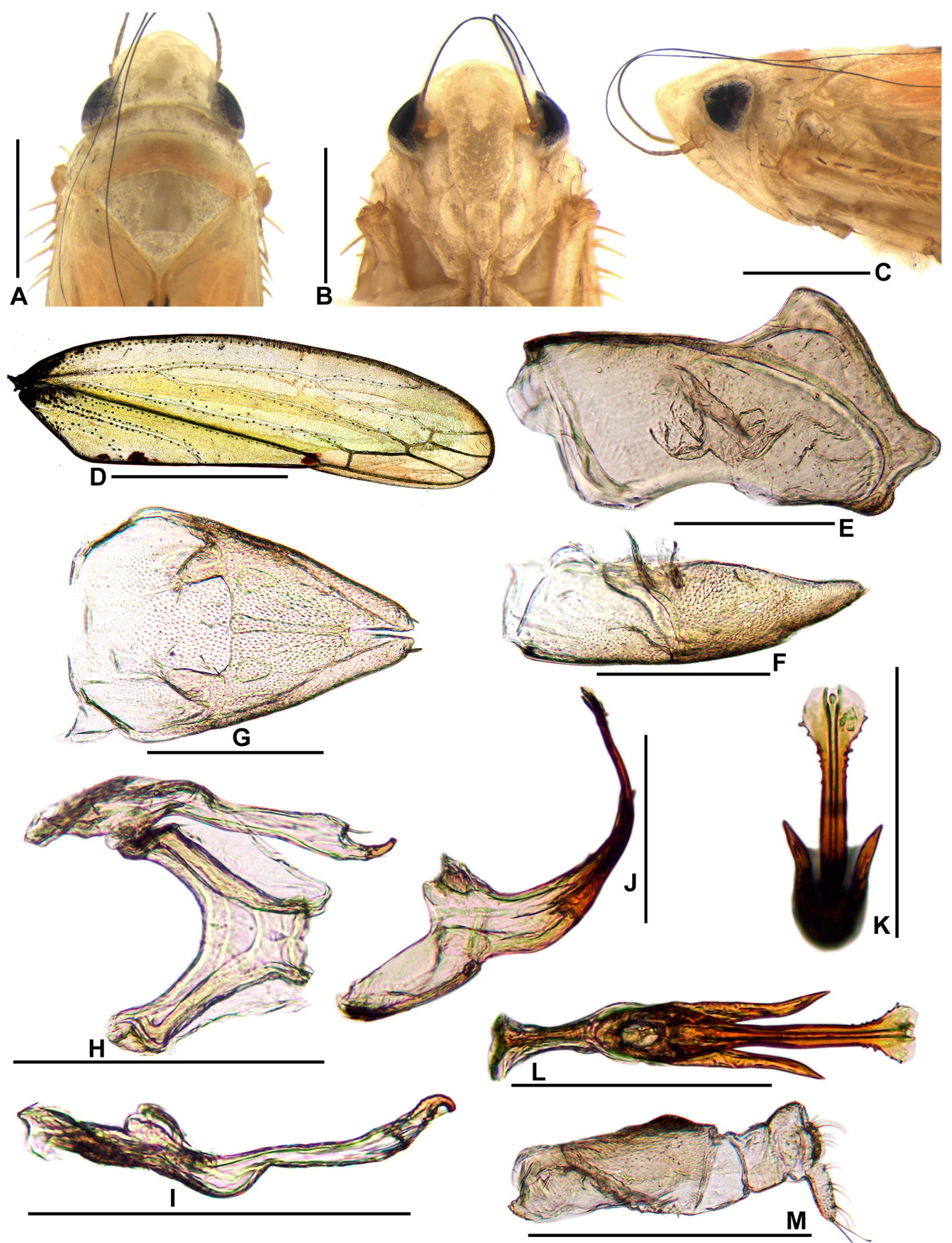

Fig. 3. Takiyaella cavichiolii gen. et sp. nov., ð, holotype (DZUP 492451). A. Head and thorax, dorsal view. B. Head, frontal view. C. Head and thorax, lateral view. D. Forewing. E. Pygofer, lateral view. F. Valve and subgenital plate, lateral view. G. Valve and subgenital plate, ventral view. H. Style and connective, dorsal view. I. Style, lateral view. J. Aedeagus, lateral view. K. Aedeagus, caudal view. L. Aedeagus, ventral view. M. Anal tube, lateral view. Scale bars: $\mathrm{A}-\mathrm{C}=1.0 \mathrm{~mm}$; D $=2.0 \mathrm{~mm}$; E-I, $\mathrm{M}=0.5 \mathrm{~mm} ; \mathrm{J}-\mathrm{L}=0.4 \mathrm{~mm}$. 


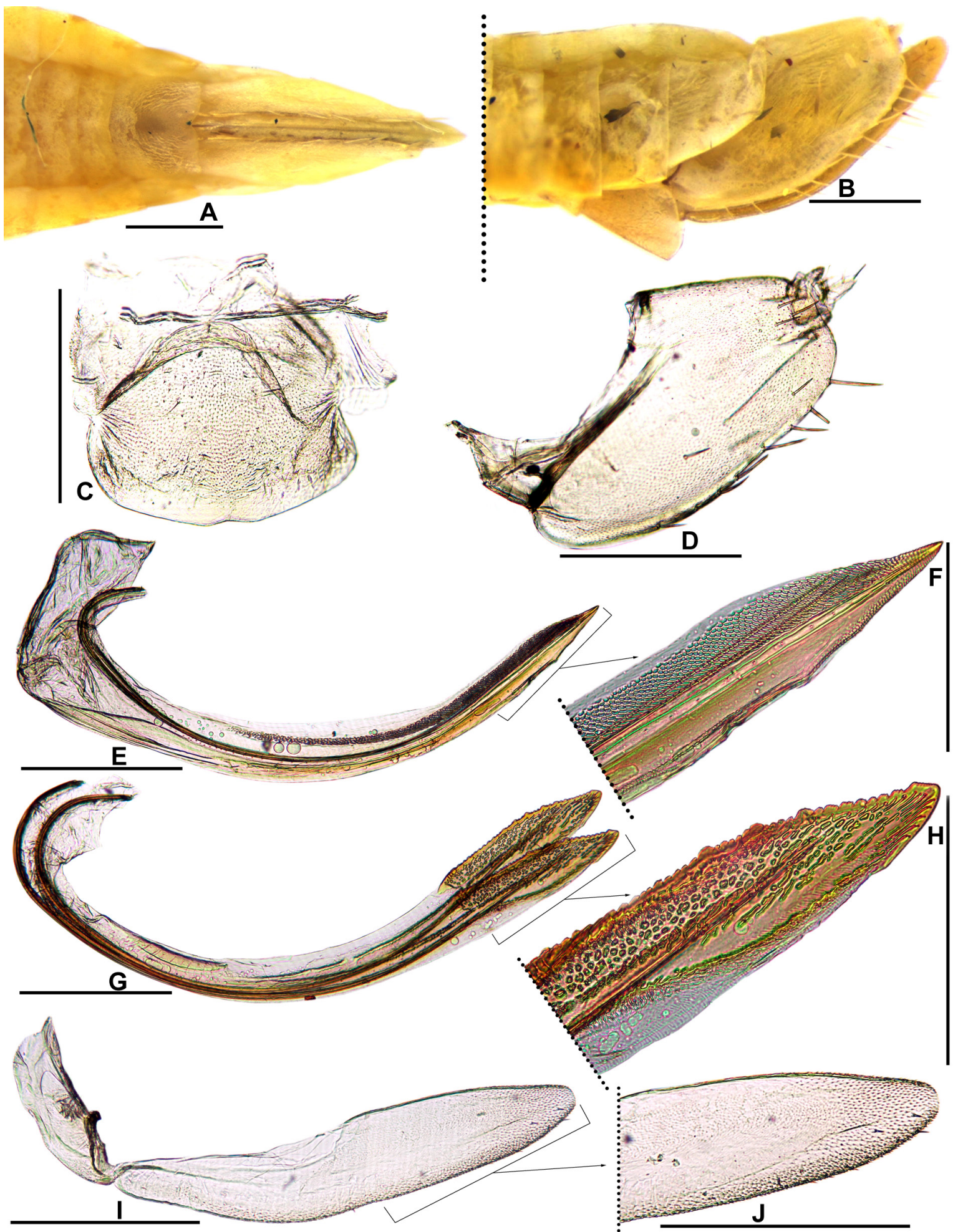

Fig. 4. Takiyaella cavichiolii gen. et sp. nov., $q$, paratype (DZUP 492477). A. Posterior portion of abdomen, ventral view. B. Posterior portion of abdomen, lateral view. C. Sternite VII, ventral view. D. Pygofer and anal tube, lateral view. E. First valvifer and first valvula of ovipositor, lateral view. F. Apex of first valvula, lateral view. G. Second valvula of ovipositor, lateral view. H. Apex of second valvula, lateral view. I. Second valvifer and gonoplac, lateral view. J. Apex of gonoplac, lateral view. Scale bars: A-B $=1.0 \mathrm{~mm}$; C-E, G, I $=0.5 \mathrm{~mm} ; \mathrm{F}, \mathrm{H}, \mathrm{J}=0.3 \mathrm{~mm}$. 
48.696 ${ }^{\circ}$ W; alt. 50 m; 23-27 Oct. 2017; A. Domahovski, G. Melo, A. Pinto and M. Savaris leg.; Malaise

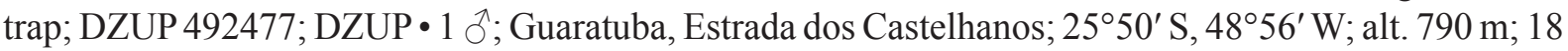
Oct.-2 Nov. 2003; Ivanir leg.; Malaise trap; DZRJ-AUCH \#241 • $1 \delta^{\lambda}$; Morretes, P.E. [Parque Estadual] do Marumbi, caminho para Estação Eng. [Engenheiro] Lange; 25⒉ $5^{\prime} 41^{\prime \prime} \mathrm{S}, 4^{\circ} 54^{\prime} 55^{\prime \prime} \mathrm{W}$; alt. $330 \mathrm{~m}$; 27 Sep. 2016; A.C. Domahovski leg.; sweep; DZUP 492460; DZRJ • 1 ; same collection data as for preceding; DZUP 492461; DZRJ • 1 q; Brasil, Paraná, Morretes; 23 Feb. 2018; A.C. Domahovski leg; sweep; DZUP 492450; DZUP • 1 o ; Piraquara, Mananciais da Serra; 2529'47" S, 48 58'54" W; alt. 1021 m; 21-28 Nov. 2018; A.P. Pinto, B.R. Araujo and A.C. Domahovski leg.; sweep; DZUP 083595; DZUP • 10̄; São José dos Pinhais, Br277 km 54 (Torre - Telepar); 2533'18" S, 4858'22" W; alt. 1060 m; 1-15 Oct. 2015; A.C. Domahovski and RRC [R.R.Cavichioli] leg.; Malaise trap; DZUP

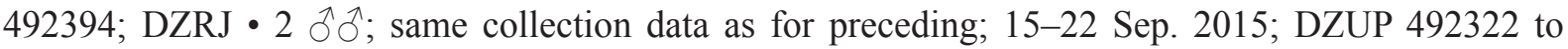
492323; DZUP.

\section{Description}

Measurements (mm). Holotype $\left({ }^{\Uparrow}\right)$ : total length 6.8. Paratypes $\left.\left({ }^{\Uparrow}\right): 6.5-6.8(\mathrm{n}=6) ;(+)\right) 7.1-7.4(\mathrm{n}=6)$.

Coloration. Pale yellow (Fig. 12C-D). Forewing (Fig. 3D) translucent, with three small dark maculae on claval comissure: first, smaller, between base and second anal vein, second, between anal veins, and third on apex of clavus and extending to brachial cell; in some specimens the first pair is absent, and in one specimen, first and second pairs are absent.

Head and thorax. External morphological characters as in generic description.

Male terminalia. Pygofer, in lateral view (Fig. 3E), $1.5 \times$ as long as maximum height, expanded apically, apical portion higher than basal portion; dorsal margin with prominent preapical subtriagular lobe; ventral tooth broadly rounded; caudal margin with ventral rounded lobe; few small setae scattered on apical half; apical portion with inner integument thickening. Subgenital plate, in lateral view (Fig. 3F), subtriangular, $3.3 \times$ as long as maximum height, slightly expanded medially; in ventral view (Fig. $3 \mathrm{G}$ ), subrhomboid, lateral margins converging anterad on basal one-fifth and converging towards apex on apical four-fifths; ventral surface with one or two pairs of apical macrosetae; apex slightly truncated. Connective (Fig. $3 \mathrm{H}$ ) V-shaped, total length approximately $2 / 3$ length of style; stem very short. Style (Fig. 3H-I) with apophysis very elongated and slender; ventral margin distinctly rounded near median third. Aedeagus (Fig. 3J-L) with pair of atrial processes parallel and following curvature of shaft, each process approximately $1 / 2$ length of shaft, broad at base and tapering towards acute apex; shaft slightly flattened dorsoventrally, apical portion expanded laterally, spatulate, lateral margins with some small spiniform projections. Anal tube (Fig. 3M) with sternite X long and tubular, with triangular basiventral process with denticles.

Female terminalia. Sternite VII (Fig. 4A-C) as long as wide; posterior margin slightly excavated medially. First valvula of ovipositor (Fig. 4F) with dorsal sculptured area areolate-strigate. Other characters as in generic description.

\section{Remarks}

Takiyaella cavichioli gen. et sp. nov. is most similar to T. sexguttata (Chiamolera \& Cavichioli, 2003) gen. et comb. nov. by the shape of male pygofer with two lobes, one dorsal and one apical (Figs 3E, 10D) and the shape of the aedeagal shaft expanded apically, with lateral margins rounded, bearing several small spiniform projections (Figs 3J-L, 10I-J). However, T. cavichioli gen. et sp. nov. differs in having the style slender and the aedeagus with atrial processes parallel to the shaft and following its curvature (Fig. 3J), while in T. sexguttata gen. et comb. nov. the style is wider, and the atrial processes are shorter, not parallel to the shaft (Fig. 10I). 
Takiyaella coelhomarquesae gen. et sp. nov. urn:lsid:zoobank.org:act:327A360B-940E-48B3-A681-37423842E88E

Figs $5-6,12 \mathrm{E}-\mathrm{F}, 13$

\section{Diagnosis}

Male pygofer (Fig. 5E) expanded apically, with apical lobe. Aedeagus (Fig. 5J-K) with two pairs of slender atrial processes anterior to shaft curvature, one pair curved dorsally, and the second directed ventrally; shaft with apical portion expanded laterally forming a small process on each side; anal tube (Fig. 5L) with basiventral process truncated with few denticles.

\section{Etymology}

The specific epithet is a tribute to Prof. Dr Ana Paula Coelho-Marques in recognition of her remarkable contribution to our knowledge of the Brazilian Auchenorrhyncha, mainly in the study of neocoelidiines.

\section{Material examined}

\section{Holotype}

BRAZIL • đ̂; Rio de Janeiro, Nova Friburgo, Macaé de Cima; alt. 1250 m; Nov.-Dec. 2009; [P.C.] Grossi leg.; DZUP-083605; DZUP.

\section{Paratypes}

BRAZIL - Rio de Janeiro • $1 \hat{\jmath}, 2$ 우; same collection data as for holotype; DZUP-083606; DZUP - $1 \hat{\jmath}$, same collection data as for holotype; DZRJ-AUCH \#242; DZRJ • 1 q; same collection data as for holotype; DZRJ-AUCH \#243; DZRJ.

\section{Description}

MeAsurements (mm). Holotype (ð): total length 6.3. Paratypes (ð): 6.2-6.5 (n=2); (ㅇ) 6.9-7.1 (n=3).

Coloration. Pale yellow (Fig. 12E-F). Forewing (Fig. 5D) translucent, with three small dark maculae on claval comissure: first, smaller, between base and second anal vein, second, between anal veins, and third on apex of clavus and extending to brachial cell.

HEAD AND THORAX. External morphological characters as in generic description.

Male terminalia. Pygofer, in lateral view (Fig. 5E), $1.7 \times$ as long as maximum height, expanded apically, apical portion higher than basal portion; dorsal margin slightly concave medially; ventral tooth slightly rounded; caudal margin truncated with small ventral rounded lobe; few small setae scattered near ventral margin and apical half; apical portion with inner integument thickening. Subgenital plate, in lateral view (Fig. 5F), subtriangular, $3.3 \times$ as long as maximum height; in ventral view (Fig. 5G), subovoid, lateral margins converging towards apex; ventral surface with pair of uniseriate rows of 5-6 macrosetae; apex acutely rounded. Connective (Fig. $5 \mathrm{H}$ ) V-shaped, total length approximately $2 / 3$ length of style; stem very short. Style (Fig. 5H-I) with dorsal margin of apodeme broadly rounded; apophysis elongated and robust. Aedeagus (Fig. 5J-K) with two pairs of slender atrial processes with acute apexes: first more dorsal in comparison to second, longer, approximately $1 / 3$ ength of shaft, curved dorsally, anterior to shaft curvature; second pair, shorter, approximately $1 / 3$ length of first, directed ventrally; shaft tubular, slightly flattened dorsoventrally at apex, ventral surface with longitudinal row of denticles on each side, extending from base to apex, apical portion expanded laterally forming small process on each side. Anal tube (Fig. 5E, L) with sternite X long and tubular, with basiventral process truncated, with few denticles. 

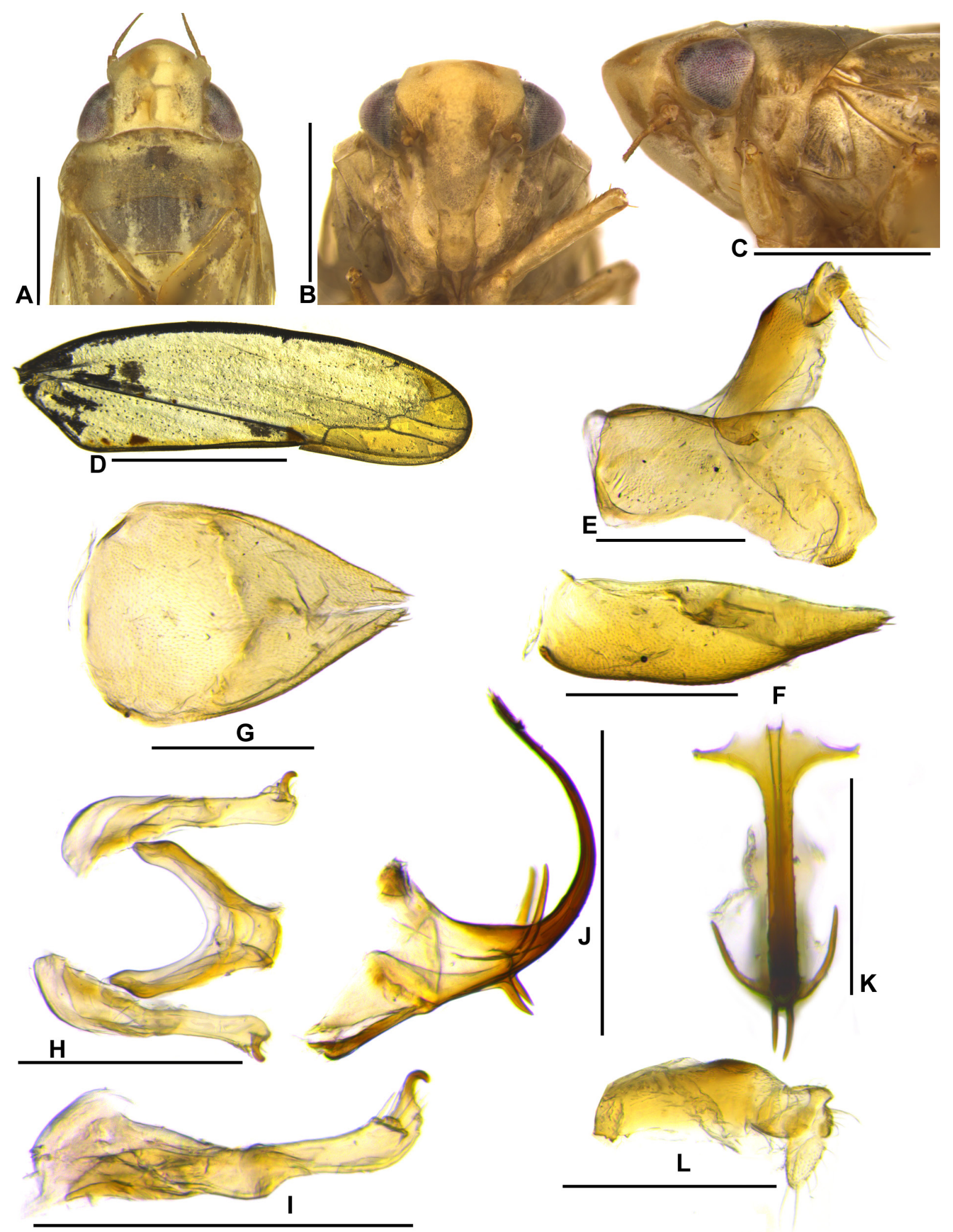

\section{E}
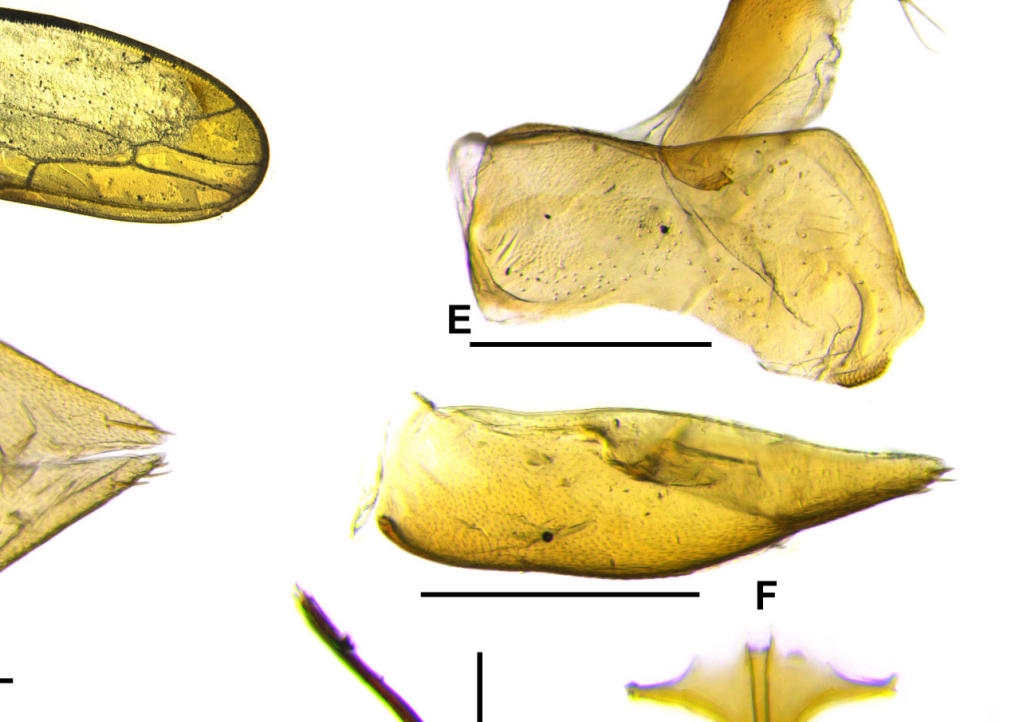

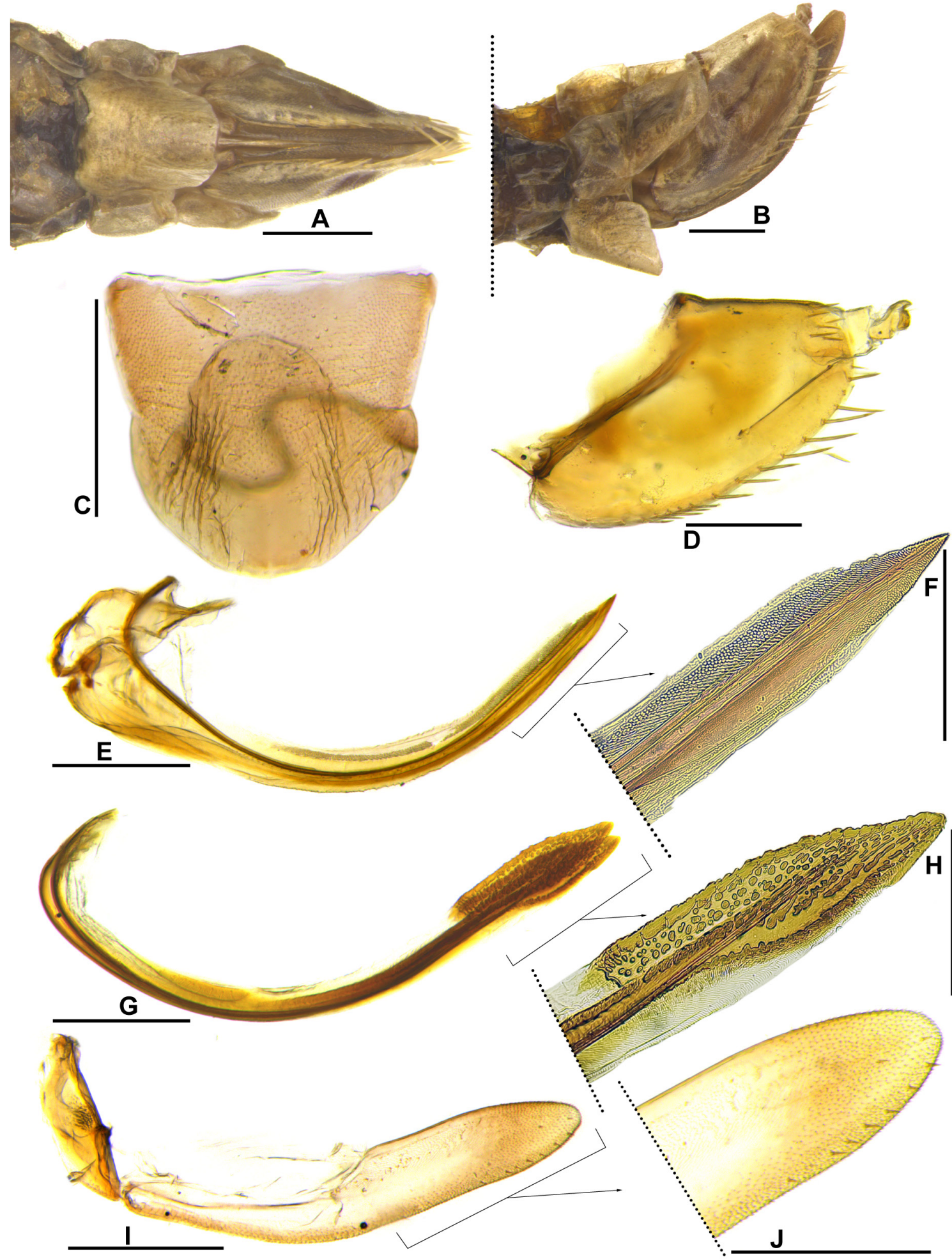

Fig. 6. Takiyaella coelhomarquesae gen. et sp. nov.,, , paratype (DZUP-083606). A. Posterior portion of abdomen, ventral view. B. Posterior portion of abdomen, lateral view. C. Sternite VII, ventral view. D. Pygofer and anal tube, lateral view. E. First valvifer and first valvula of ovipositor, lateral view. F. Apex of first valvula, lateral view. G. Second valvula of ovipositor, lateral view. H. Apex of second valvula, lateral view. I. Second valvifer and gonoplac, lateral view. J. Apex of gonoplac, lateral view. Scale bars: A-B $=1.0 \mathrm{~mm}$; C-E, G, I $=0.5 \mathrm{~mm} ; \mathrm{F}, \mathrm{H}, \mathrm{J}=0.3 \mathrm{~mm}$. 
Female terminalia. Sternite VII (Fig. 6A-C) as long as wide; lateral margins constricted medially. First valvula of ovipositor (Fig. 6F) with dorsal sculptured area baculiform. Other characters as in generic description.

\section{Remarks}

Takiyaella coelhomarquesae gen. et sp. nov. is most similar to T. daniela gen. et sp. nov. by the shape of apex of aedeagus expanded laterally forming a small process on each side (Figs 5K, 7K). However, T. coelhomarquesae gen. et sp. nov. differs by the dorsal margin of the male pygofer without distinct lobe (Fig. 5E); aedeagus with two pairs of atrial processes (Fig. 5J) and anal tube with basiventral process (Fig. 5L). While T. daniela gen. et sp. nov. have the dorsal margin of the male pygofer with distinct lobe (Fig. 7E); aedeagus with a pair of bifid atrial processes (Fig. 7J) and anal tube without basiventral process (Fig. 7E).

Takiyaella daniela gen. et sp. nov. urn:1sid:zoobank.org:act:3E9E3765-EC80-4B1E-BBD2-0BE402754538

Figs $7,12 \mathrm{G}-\mathrm{H}, 13$

\section{Diagnosis}

Male pygofer (Fig. 7E) expanded apically, with two lobes, a larger dorsal lobe and a smaller subacute apical lobe. Aedeagus (Fig. 7J-K) with atrial processes bifid, dorsal ramus about $3 \times$ as large as ventral ramus, both acute. shaft expanded laterally forming small process on each side.

\section{Etymology}

The specific epithet is a tribute to Prof. Dr Daniela Maeda Takiya in recognition of her remarkable contribution to our knowledge of the Brazilian Auchenorrhyncha, and also in gratitude for her great friendship and for bringing the first author to the study of leafhoppers. The species epithet is treated as a noun in apposition.

\section{Material examined}

\section{Holotype}

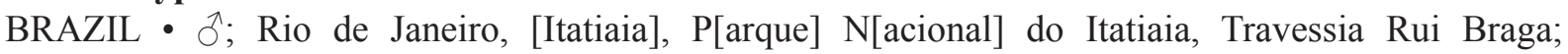
$22^{\circ} 25^{\prime} 50.4^{\prime \prime} \mathrm{S}, 4^{\circ} 37^{\prime} 12.6^{\prime \prime} \mathrm{W}$; alt. 1100 m; 12 Oct. 2003; D.M. Takiya, C. Moraes and C.C. Gonçalves leg.; sweep; DZRJ-AUCH \#244; DZRJ.

\section{Paratypes}

BRAZIL - Rio de Janeiro - 1 đ̇; Itatiaia, Parque Nacional do Itatiaia, Setor Lago Azul, mata; $22^{\circ} 27^{\prime} 1.10^{\prime \prime} \mathrm{S}, 44^{\circ} 36^{\prime} 55.30^{\prime \prime} \mathrm{W}$; alt. $830 \mathrm{~m}$; 1 Jul.-3 Aug. 2015; Biota FAPERJ leg.; malaise; MNRJ - 1 ' ; Itatiaia, P[arque] N[acional] do Itatiaia, Alojamento $2 ; 22^{\circ} 27^{\prime} 7.86^{\prime \prime} \mathrm{S}, 44^{\circ} 36^{\prime} 27.95^{\prime \prime} \mathrm{W}$; alt. $840 \mathrm{~m}$; 25-29 Oct. 2019; A.C. Domahovski leg.; sweep; DZUP-083607; DZUP.

\section{Description}

Measurements (mm). Holotype (ふ): total length 6.5. Paratypes $(ð): 6.3-6.6(\mathrm{n}=2)$.

Coloration. Pale yellow (Fig. 12G-H). Forewing (Fig. 7D) translucent, with three small dark maculae on claval comissure: first, between base and second anal vein; second between anal veins and third on apex of clavus and extending to brachial cell.

HEAD AND THORAX. External morphological characters as in generic description. 

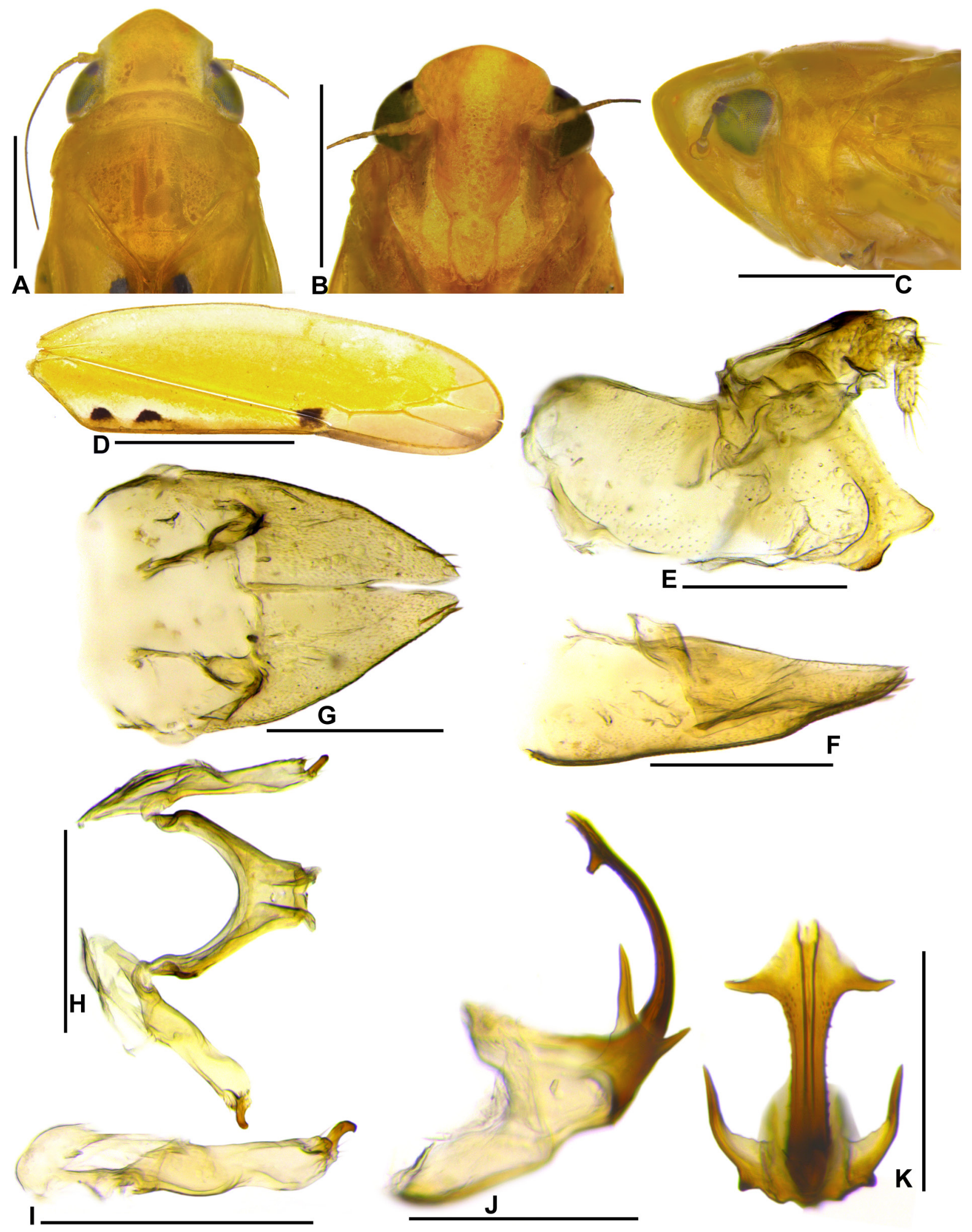

Fig. 7. Takiyaella daniela gen. et sp. nov., $\widehat{\jmath}$, holotype (DZRJ-AUCH \#244). A. Head and thorax, dorsal view. B. Head, frontal view. C. Head and thorax, lateral view. D. Forewing. E. Pygofer and anal tube, lateral view. F. Valve and subgenital plate, lateral view. G. Valve and subgenital plate, ventral view. H. Styles and connective, dorsal view. I. Style, lateral view. J. Aedeagus, lateral view. K. Aedeagus, caudal view. Scale bars: A-C $=1.0 \mathrm{~mm} ; \mathrm{D}=2.0 \mathrm{~mm}$; $\mathrm{E}-\mathrm{I}=0.5 \mathrm{~mm} ; \mathrm{J}-\mathrm{K}=0.4 \mathrm{~mm}$. 
Male terminalia. Pygofer, in lateral view (Fig. 7E), $1.8 \times$ as long as maximum height, expanded apically; dorsal margin with prominent preapical lobe; caudal margin with ventral subacute lobe; ventral tooth broadly rounded; apical portion with inner integument thickening. Subgenital plate, in lateral view (Fig. 7F), subtriangular, $2.9 \times$ as long as maximum height; in ventral view (Fig. 7G), subovoid, lateral margins converging towards apex; ventral surface with pair of uniseriate rows of 3-4 macrosetae; apex acute. Connective (Fig. 7H) V-shaped, total length approximately $2 / 3$ length of style; stem very short. Style (Fig. 7H-I) with apophysis elongated and robust. Aedeagus (Fig. 7J-K) with pair of bifid atrial process: dorsal ramus about $1 / 3$ length of shaft, directed dorsally, anterior to curvature of shaft; ventral ramus approximately $1 / 3$ length of dorsal ramus, directed posteriorly, posterior to curvature of shaft; shaft tubular, slightly flattened dorsoventrally at apex, ventral surface with longitudinal row of denticles on each side, extending from base to apex, apical portion expanded laterally forming small process on each side. Anal tube (Fig. 7E) with sternite X long and tubular, without basiventral process.

Female terminalia. Female unknown.

\section{Remarks}

Takiyaella daniela gen. et sp. nov. is easily distinguished from other species of the genus by having atrial process bifid apically (Fig. $7 \mathrm{~J}-\mathrm{K}$ ).

Takiyaella mejdalanii gen. et sp. nov. urn:1sid:zoobank.org:act:83EC235F-172B-4A24-BC70-66CF0586F9C9

Figs 8-9, 12I-J, 13

\section{Diagnosis}

Male pygofer (Fig. 8E) strongly expanded apically, with apical lobe. Aedeagus (Fig. 8J-K) with atrial processes large, flattened laterally, directed caudally and bent dorsally; shaft short, flattened laterally on basal half and dorsoventrally on apical half, apex expanded with laterodorsal spiniform projections. Anal tube (Fig. 8E) with basal portion produced anteroventrally bearing moderately long basiventral acute teeth.

\section{Etymology}

The specific epithet is a tribute to Prof. Dr Gabriel Mejdalani in recognition of his remarkable contribution to our knowledge of the Brazilian Cicadellidae.

\section{Material examined}

\section{Holotype}

BRAZIL - O’; Minas Gerais, Catas Altas, R[eserva] P[articular do] P[atrimônio] N[atural] Santuário do Caraça, Ribeirão Caraça, Cascatona; 204'17.8" S, 43²9'17.7" W; alt. 1200 m; 17 Mar. 2015; A.L.D. Ferreira leg.; sweep; DZRJ-AUCH \#246; DZRJ.

\section{Paratypes}

BRAZIL - Minas Gerais • 1 क ; same collection data as for holotype; DZRJ-AUCH \#247; DZRJ • 1 万; Catas Altas, RPPN Santuário do Caraça, Trilha Bocaina; 206'35.2" S, 4329'12" W; alt. 1289 m; 16 Mar. 2015; C.H. Dietrich leg.; sweep; DZRJ-AUCH \#248; DZRJ・ 1 ô'; São Gonçalo do Rio de Baixo, Estação Ambiental de Peti, Cemig; 21 Feb. 2002; A.F. Kumagai leg.; Malaise trap; DZUP-083608;

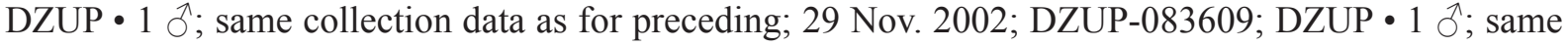
collection data as for preceding; 13 Dec. 2002; DZUP-083610; DZUP• 1 q; same collection data as for preceding; 24 Jan. 2003; DZUP-083611; DZUP. 

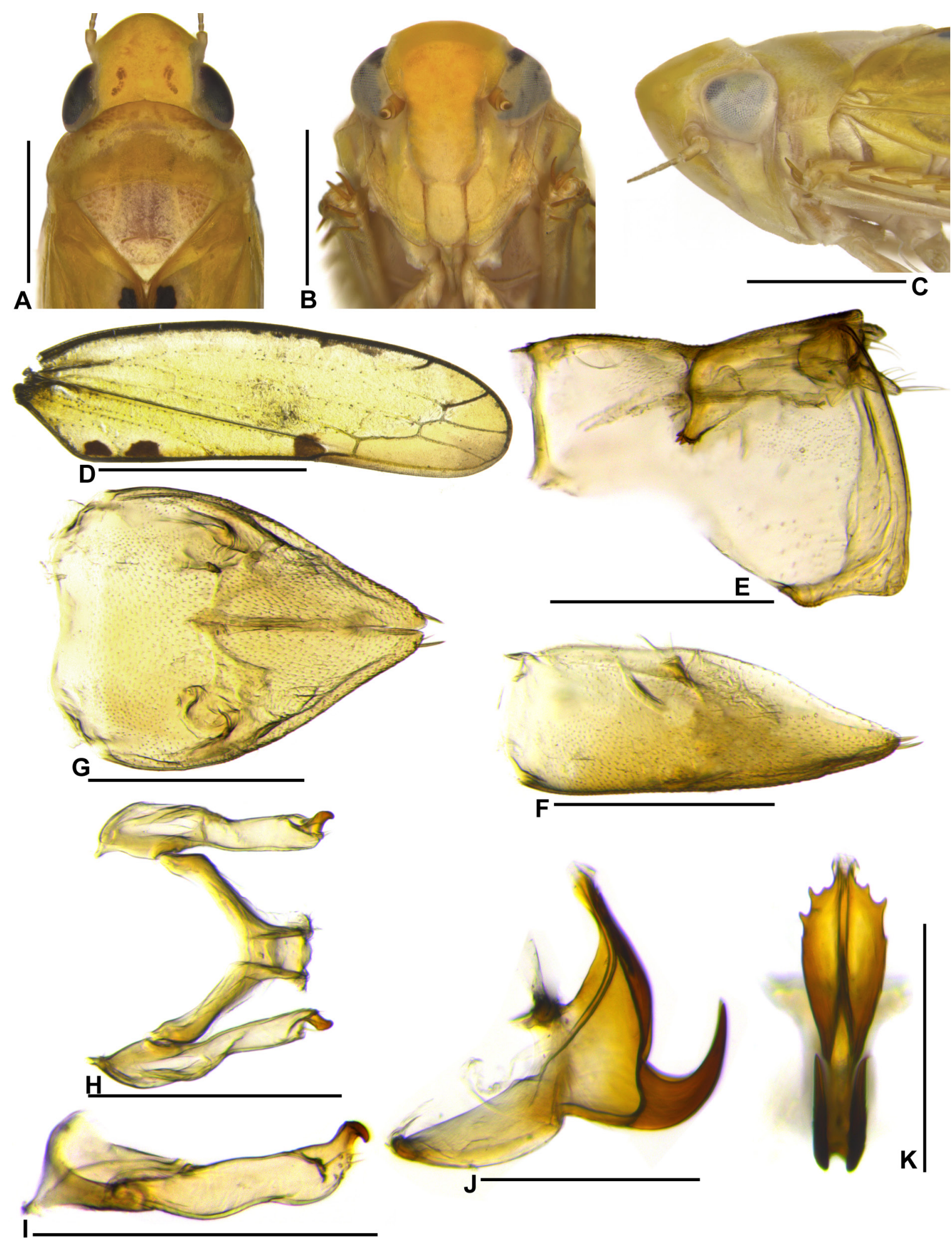

Fig. 8. Takiyaella mejdalanii gen. et sp. nov., ô, holotype (DZRJ-AUCH \#246). A. Head and thorax, dorsal view. B. Head, frontal view. C. Head and thorax, lateral view. D. Forewing. E. Pygofer and anal tube, lateral view. F. Valve and subgenital plate, lateral view. G. Valve and subgenital plate, ventral view. H. Styles and connective, dorsal view. I. Style, lateral view. J. Aedeagus, lateral view. K. Aedeagus, caudal view. Scale bars: $\mathrm{A}-\mathrm{C}=1.0 \mathrm{~mm} ; \mathrm{D}=2.0 \mathrm{~mm}$; $-\mathrm{I}=0.5 \mathrm{~mm} ; \mathrm{J}-\mathrm{K}=0.4 \mathrm{~mm}$. 


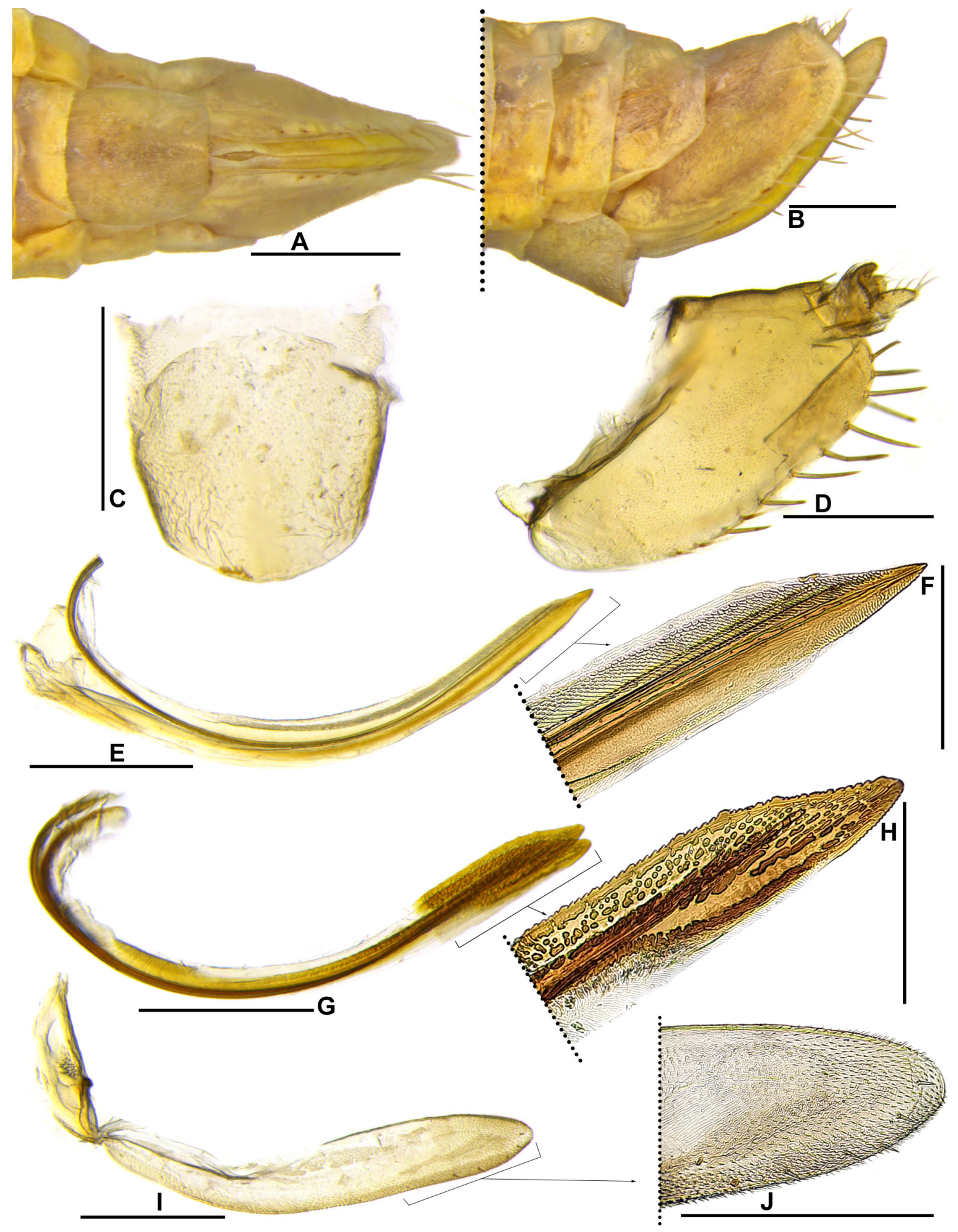

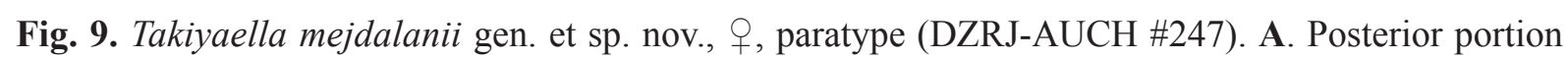
of abdomen, ventral view. B. Posterior portion of abdomen, lateral view. C. Sternite VII, ventral view. D. Pygofer and anal tube, lateral view. E. First valvula of ovipositor, lateral view. F. Apex of first valvula, lateral view. G. Second valvula of ovipositor, lateral view. H. Apex of second valvula, lateral view. I. Second valvifer and gonoplac, lateral view. J. Apex of gonoplac, lateral view. Scale bars: $\mathrm{A}-\mathrm{B}=1.0 \mathrm{~mm}$; C-E, G, I $=0.5 \mathrm{~mm} ; \mathrm{F}, \mathrm{H}, \mathrm{J}=0.3 \mathrm{~mm}$. 


\section{Description}

Measurements (mm). Holotype ( $\overbrace{}^{\Uparrow})$ : total length 6. Paratypes $\left({ }^{\Uparrow}\right)$ : 6.0-6.5 $(\mathrm{n}=4) ;(+)$ ) 6.8-6.9 $(\mathrm{n}=2)$.

Coloration. Pale yellow (Fig. 12I-J). Forewing (Fig. 8D) translucent, with three dark maculae on claval comissure: first, between base and second anal vein; second, between anal veins and third on apex of clavus and extending to brachial cell.

HEAD AND THORAX. External morphological characters as in generic description.

Male terminalia. Pygofer, in lateral view (Fig. 8E), $1.3 \times$ as long as maximum height, strongly expanded apically, apical portion twice as high as basal portion; dorsal margin slightly concave medially; caudal margin truncated with small ventral rounded lobe; ventral tooth slightly rounded; apical portion with inner integument thickening. Subgenital plate, in lateral view (Fig. 8F), subtriangular, $2.6 \times$ as long as maximum height, narrowing at apical fourth; in ventral view (Fig. 8G), cordiform, lateral margins converging towards apex; ventral surface with pair of uniseriate rows of 2-3 macrosetae; apex acutely rounded. Connective (Fig. $8 \mathrm{H}$ ) V-shaped, total length approximately $2 / 3$ length of style; stem short. Style (Fig. 8H-I) with dorsal margin of apodeme rounded; apophysis elongated and robust. Aedeagus (Fig. 8J-K) with pair of large atrial processes, approximately $1 / 2$ length of shaft, flattened laterally, posterior to curvature of the shaft, directed caudally and bent dorsally, wide at base and narrowing towards acute apex; shaft short, flattened laterally on basal half and dorsoventrally on apical half; apex slightly expanded with 2-3 pairs of laterodorsal spiniform projections. Anal tube (Fig. 8E) with sternite $\mathrm{X}$ long and tubular, basal portion produced anteroventrally bearing moderately long basiventral acute teeth.

Female terminalia. Sternite VII (Fig. 9A-C) slightly wider than long; lateral margins parallel. First valvula of ovipositor (Fig. 6F) with dorsal sculptured area areolate-strigate. Other characters as in generic description.

\section{Remarks}

Takiyaella mejdalanii gen. et sp. nov. resembles T. cavichiolii gen. et sp. nov. and T. sexguttata gen. et comb. nov. by the apical portion of the aedeagus with lateral spiniform projections (Figs $3 \mathrm{~K}, 8 \mathrm{~K}, 10 \mathrm{~J}$ ). However, T. mejdalanii gen. et sp. nov. differs from other species of the genus by the shape of the male pygofer, strongly expanded apically (Fig. $8 \mathrm{E}$ ) and by the shape and direction of the atrial processes of the aedegus (Fig. 8J-K).

Takiyaella sexguttata (Chiamolera \& Cavichioli, 2003) gen. et comb. nov. Figs $10-11,12 \mathrm{~K}-\mathrm{M}, 13$

Xenocoelidia sexguttata Chiamolera \& Cavichioli, 2003: 199: figs 1-7.

\section{Diagnosis}

Male pygofer (Fig. 10D) expanded apically, dorsal margin with small rounded lobe, caudal margin with ventral rounded lobe. Aedeagus (Fig. 10I-K) with atrial processes slender, curved dorsally, not following the curvature of shaft; shaft expanded apically, spatulate, with small lateral spiniform projections; anal tube (Fig. 10L) with basiventral process triangular.

\section{Material examined}

Holotype

BRAZIL• ○’; Rio de Janeiro, Silva Jardim; Mar. 1974; F.M. Oliveira leg.; DZUP-082927; DZUP. 

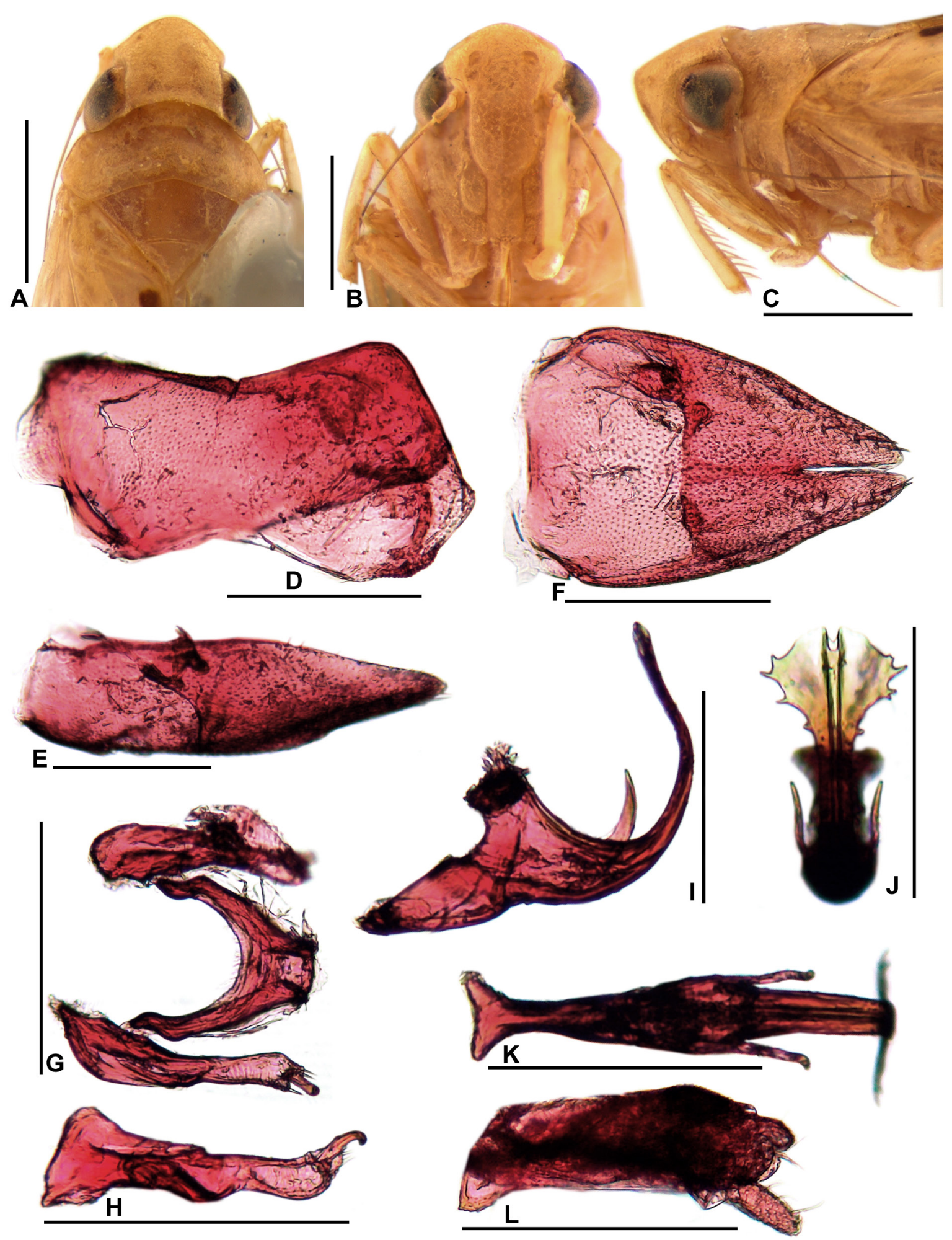

Fig. 10. Takiyaella sexguttata (Chiamolera \& Cavichioli, 2003) gen. et comb. nov., Ô, holotype (DZUP-082927). A. Head and thorax, dorsal view. B. Head, frontal view. C. Head and thorax, lateral view. D. Pygofer, lateral view. E. Valve and subgenital plate, lateral view. F. Valve and subgenital plate, ventral view. G. Styles and connective, dorsal view. H. Style, lateral view. I. Aedeagus, lateral view. J. Aedeagus, caudal view. K. Aedeagus, ventral view. L. Anal tube, lateral view. Scale bars: $\mathrm{A}-\mathrm{C}=1.0 \mathrm{~mm} ; \mathrm{D}-\mathrm{H}, \mathrm{L}=0.5 \mathrm{~mm} ; \mathrm{I}-\mathrm{K}=0.4 \mathrm{~mm}$. 


\section{Paratypes}

BRAZIL - Rio de Janeiro • 1 đ̆; same collection data as for holotype; DZUP-492337; DZUP • 1 क; same collection data as for holotype; VIII.1975; DZUP-492336; DZUP.

\section{Description}

Measurements (mm). Holotype $\left({ }^{\Uparrow}\right)$ : total length 6.1. Paratypes $(ð): 6.1(\mathrm{n}=1) ;(+) 6.7(\mathrm{n}=1)$.

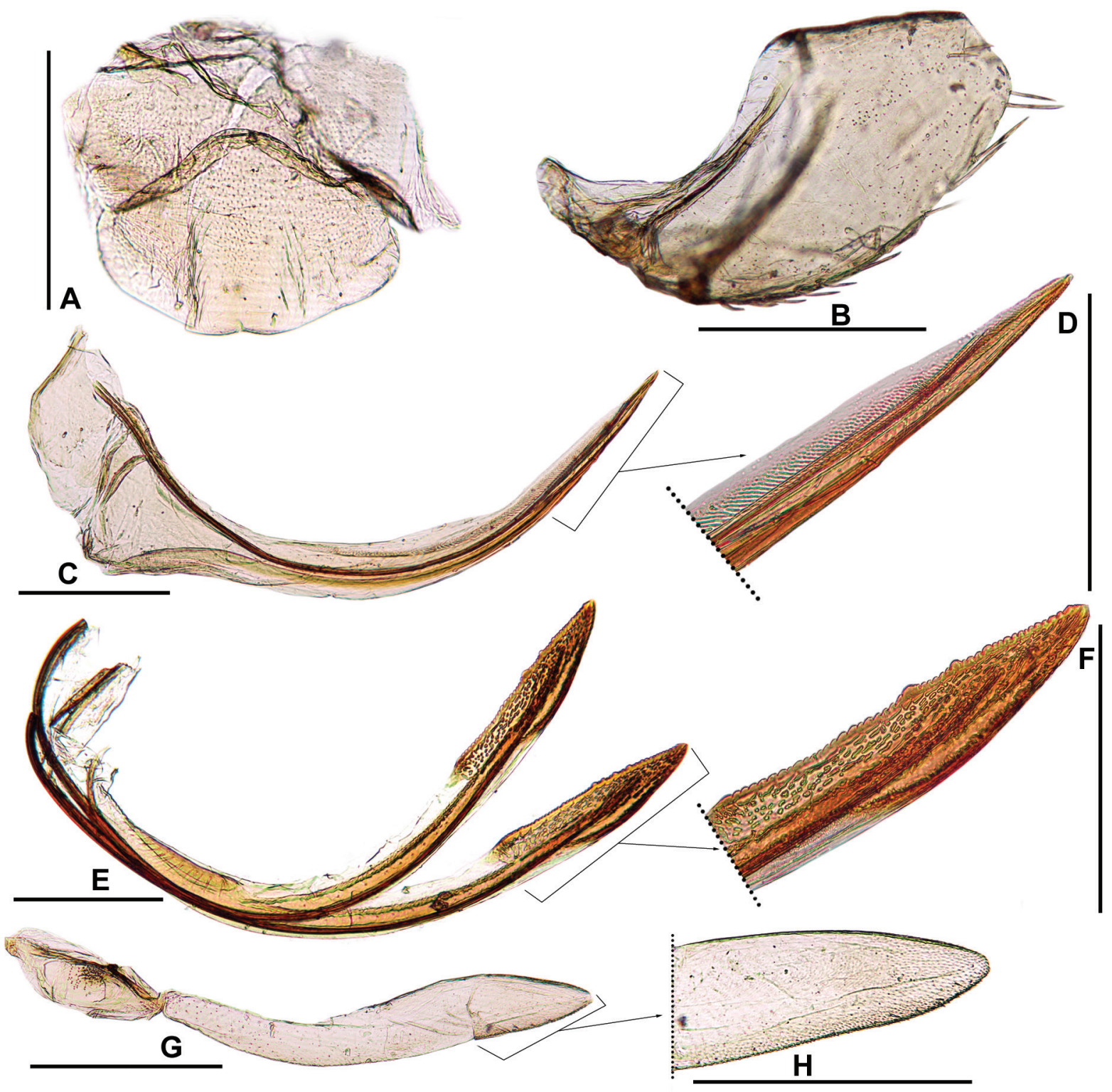

Fig. 11. Takiyaella sexguttata (Chiamolera \& Cavichioli, 2003) gen. et comb. nov., + , paratype (DZUP-492337). A. Sternite VII, ventral view. B. Pygofer and anal tube, lateral view. C. First valvula of ovipositor, lateral view. D. Apex of first valvula, lateral view. E. Second valvula of ovipositor, lateral view. F. Apex of second valvula, lateral view. G. Second valvifer and gonoplac, lateral view. H. Apex of gonoplac, lateral view. Scale bars: A-C, E, G $=0.5 \mathrm{~mm}$; D, F, H $=0.3 \mathrm{~mm}$. 


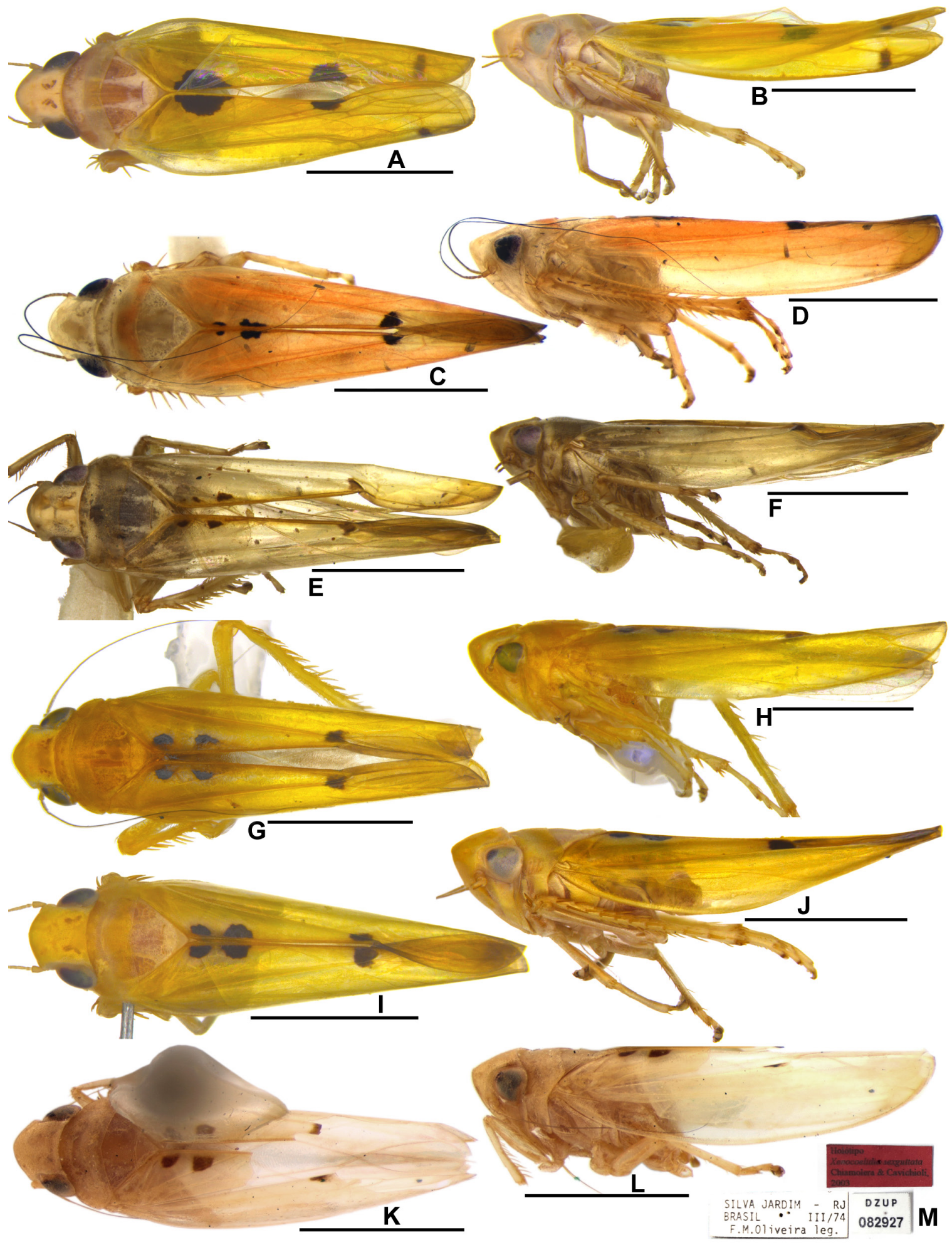

Fig. 12. Habitus of type specimens, dorsal and lateral view, respectively. A-B. Takiyaella anomala gen.

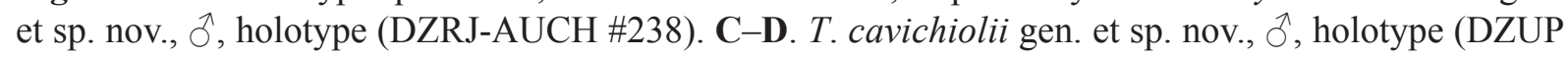

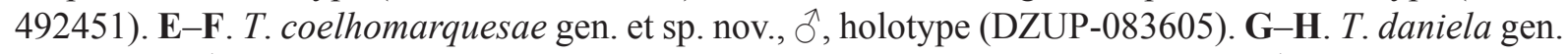
et sp. nov., Oे, holotype (DZRJ-AUCH \#244). I-J. T. mejdalanii gen. et sp. nov., §, holotype (DZRJAUCH \#246). K-L. T. sexguttata (Chiamolera \& Cavichioli, 2003) gen. et comb. nov., Õ, holotype (DZUP-082927). M. Labels of the holotype of Xenocoelidia sexguttata. Scale bars: A-L $=2.0 \mathrm{~mm}$. 
Coloration. Pale yellow (Fig. 12K-L). Forewing (Fig. 12K-L) translucent, with three dark maculae on claval comissure: first, between base and second anal vein; second, between anal veins and third on apex of clavus and extending to brachial cell.

HEAD AND THORAX. External morphological characters as in generic description.

Male terminalia. Pygofer, in lateral view (Fig. 10D), $1.7 \times$ as long as maximum height, expanded apically; dorsal margin concave medially with small preapical rounded lobe; caudal margin truncated with small ventral rounded lobe; ventral tooth slightly rounded; apical portion with inner integument thickening. Subgenital plate, in lateral view (Fig. 10E), subtriangular, $3.6 \times$ as long as maximum height, narrowing at apical fourth; in ventral view (Fig. 10F), subrhomboid, lateral margins converging towards apex; ventral surface with pair of uniseriate rows of 4-5 macrosetae; apex acutely rounded. Connective (Fig. 10G) V-shaped, total length approximately $2 / 3$ length of style; stem short. Style (Fig. 10G-H) with dorsal margin of apodeme rounded; apophysis elongated and robust. Aedeagus (Fig. 10I-K) with pair of atrial processes curved dorsally, with $1 / 3$ length of shaft, anterior to curvature of shaft and not following its curvature broad at base and tapering towards apex; shaft slightly flattened dorsoventrally, apical portion expanded laterally, spatulate, lateral margins with some small spiniform projections. Anal tube (Fig. 10L) with sternite $\mathrm{X}$ long and tubular, basal portion with basiventral process triangular, with few denticles.

Female terminalia. Sternite VII (Fig. 11A) slightly wider than long; lateral margins constricted medially; posterior margin slightly emarginated. First valvula of ovipositor (Fig. 11D) with dorsal sculptured area areolate-strigate. Other characters as in generic description.

\section{Remarks}

Xenocoelidia sexguttata was described by Chiamolera \& Cavichioli (2003) based on two males and one female from Rio de Janeiro, Brazil. Our study of the X. sexguttata types (Figs 10-11, 12K-L) indicated the following morphological incongruities with the other species of Xenocoelidia: (1) male pygofer with

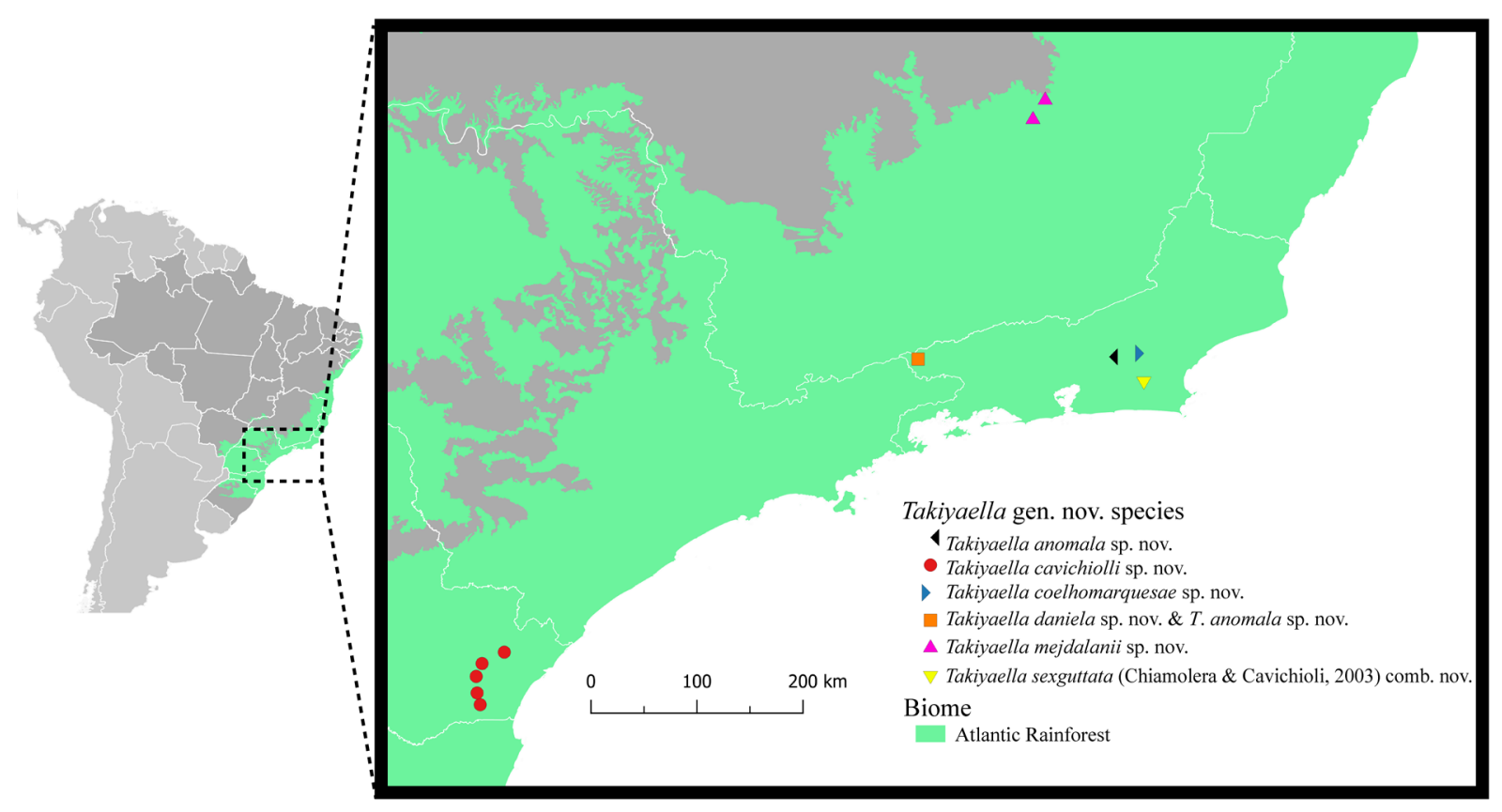

Fig. 13. Distribution map of all known species of Takiyaella gen. nov. 
caudal margin with small lobe without robust setae (Fig. 10D), whereas in other species of Xenocoelidia the caudal margin of pygofer is broadly rounded bearing several small and robust setae; (2) subgenital plates fused to each other in the basal two-thirds, with only the apical third being free (Fig. 10F), while in other species the subgenital plates are fused only at base, being free for most of its length; (3) connective with stem short (Fig. 10G), while in other species the connective is Y-shaped, with stem long; (4) style with preapical lobe moderately developed and slightly produced posterad (Fig. 10H), whereas other species of Xenocoelidia have the preapical lobe strongly developed and expanded laterally; and (5) aedeagus with shaft moderately long, wider at base, bearing atrial processes (Fig. 10I), while in other species of Xenocoelidia the aedeagus lacks atrial process, and the aedeagal shaft is very long and narrow in almost all its length. Based on these differences, we propose the transfer of X. sexguttata to Takiyaella gen nov.

\section{Key to males of Takiyaella gen. nov.}

1. Forewing with black macula on fourth apical cell (Fig. 1D); pygofer not expanded apically (Fig. 1E); connective Y-shaped (Fig. 1H); aedeagal shaft with apical portion not expanded laterally (Fig. 1J$\mathrm{K})$

T. anomala gen. et sp. nov.

- Forewing without black macula on fourth apical cell (Figs 3D, 7D); pygofer expanded apically (Figs 5E, 8E); connective V-shaped (Figs 5H, 10G); aedeagal shaft with apical portion expanded laterally (Figs $7 \mathrm{~K}, 8 \mathrm{~K}$ )

2. Aedeagus with apex spatulate, lateral margins bearing small spiniform projections (Figs $3 \mathrm{~K}, 8 \mathrm{~K}$, $10 \mathrm{~J})$

- Aedeagus expanded apically forming a small lateral process on each side (Figs 5K, 7K)

3. Pygofer strongly expanded apically, dorsal margin without distinct lobe (Fig. 8E); aedeagus short, shaft flattened laterally on basal half, atrial processes, in lateral view, posterior to shaft curvature (Fig. 8J)

T. mejdalanii gen. et sp. nov.

- Pygofer moderatelly expanded apically, dorsal margin with distinct lobe (Figs 3E, 10D); aedeagus long, shaft tubular on basal half, atrial processes, in lateral view, anterior or parallel to shaft curvature (Figs 3J, 10I)

4. Aedeagus with atrial processes parallel to shaft and following its curvature (Fig. 3J)

T. cavichiolii gen. et sp. nov.

- Aedeagus with atrial processes anterior to the shaft curvature (Fig. 10I)

T. sexguttata (Chiamolera \& Cavichioli, 2003) gen. et comb. nov.

5. Aedeagus with two pairs of atrial processes (Fig. 5J-K) .........T. coelhomarquesae gen. et sp. nov.

- Aedeagus with a pair of bifid atrial processes (Fig. 7J-K) ........................T. daniela gen. et sp. nov.

\section{Discussion}

The six species treated herein show a different combination of features from those present in the currently recognized genera, so that the establishment of a new genus was necessary to include them. Takiyaella gen. nov. belongs to the group of genera without a carina at the crown-face transition, along with Xenocoelidiana Marques-Costa \& Cavichioli, 2006, Deltocoelidia Kramer, 1961, Paraphysiana Chiamolera, Cavichioli \& Anderle, 2003, Xenocoelidia Kramer, 1959, Chinchinota Kramer, 1967 and Chinaia Bruner \& Metcalf, 1934. These genera were recovered forming a monophyletic clade in the cladistic analysis of the Neocoelidiinae proposed by Marques-Costa \& Cavichioli (2012) based on 85 morphological characters, but with low support $($ Bremer $=1)$. 
Takiyaella gen nov. differs from the other mentioned genera by the forewing (Figs 1D, 7D) with two or three dark maculae on clavus, crossvein 's' missing; hind wing with veins $\mathrm{R}_{4+5}$ and $\mathrm{M}_{1+2}$ convergent preapically and fused to each other at apex, forming a single vein; male pygofer (Figs 5E, 8E) with a sclerotized and dentated ventral tooth on apical portion and caudal margin usually with ventral rounded lobe; valve (Figs 3G, 8G) without indication of separation with subgenital plates; subgenital plates (Figs 7G, 10F) fused to each other in the basal two-thirds; connective (Figs 3H, 7H) usually with stem reduced; style (Figs 1H, 7H) with preapical lobe moderately developed; and the aedeagus (Figs 5J, 7J, $8 \mathrm{~J}$ ) with one or two pairs of atrial processes. In addition, all species known for Takiyaella gen. nov. have distribution restricted to the Atlantic Rainforest biome (Fig. 13), unlike what occurs with the species of the other genera mentioned above, which mostly are distributed in the Amazon Rainforest biome, except for Chinaia bidentata Chiamolera \& Cavichioli, 2002 that is found in the Atlantic Rainforest.

\section{Acknowledgments}

C.C. Gonçalves is currently a post-doctoral fellow from Fundação Carlos Chagas Filho de Amparo à Pesquisa do Estado do Rio de Janeiro (FAPERJ, proc. E-26/202.301/2019). A.C. Domahovski receives a doctoral fellowship from Conselho Nacional de Desenvolvimento Científico e Tecnológico (CNPq) (proc, 140815/2017-1).

\section{References}

Bruner S.C. \& Metcalf Z.P. 1934. A new Bythoscopidae from Costa Rica. Bulletin of the Brooklyn Entomological Society 29: 120-124.

Cavichioli R.R. \& Takiya D.M. 2012. Description of a new species of Wolfniana and new records of Rotigonalia (Hemiptera: Cicadellidae: Cicadellinae) from the state of Amazonas, Brazil. Zoologia 29 (1): 85-88. https://doi.org/10.1590/S1984-46702012000100011

Chiamolera L.B. \& Cavichioli R.R. 2003. Xenocoelidia Kramer: descrição de uma espécie nova (Hemiptera, Auchenorrhyncha, Neocoelidiinae). Revista Brasileira de Zoologia 20 (2): 199-200. https://doi.org/10.1590/S0101-81752003000200004

Chiamolera L.B. \& Cavichioli R.R. 2005. Notas sobre Coelidiana Oman (Hemiptera, Cicadellidae, Neocoelidiinae) com descrição de três novas espécies do Brasil. Revista Brasileira de Zoologia 22 (2): 494-500. https://doi.org/10.1590/S0101-81752005000200028

Coelho-Marques A.P. \& Ale-Rocha R. 2016. Four new species of Chinaia Bruner \& Metcalf(Hemiptera: Cicadellidae: Neocoelidiinae) from the Neotropical Region. Zootaxa 4189 (1): 145-155.

https://doi.org/10.11646/zootaxa.4189.1.7

Coelho-Marques A.P. \& Ale-Rocha R. 2017. Description of a new neotropical species of Xiqilliba Kramer (Hemiptera: Cicadellidae: Neocoelidiinae). Zootaxa 4311 (3): 409-416.

https://doi.org/10.11646/zootaxa.4311.3.6

DeLong D.M. 1953. A synopsis of the tribe Neocoelidinii in the Americas (Homoptera-Cicadellidae). Lloydia 16 (2): 93-131.

Dietrich C.H. 2003. Some unusual Neotropical Neocoelidiinae with a redefinition of the subfamily (Hemiptera: Membracoidea: Cicadellidae). Annals of the Entomological Society of America 96 (6): 700-715. https://doi.org/10.1603/0013-8746(2003)096[0700:SUNNWA]2.0.CO;2

Dietrich C.H. 2005. Keys to the families of Cicadomorpha and subfamilies and tribes of Cicadellidae (Hemiptera: Auchenorrhyncha). Florida Entomologist 88 (4): 502-517.

https://doi.org/10.1653/0015-4040(2005)88[502:KTTFOC]2.0.CO;2 
Dietrich C.H., Allen J.M., Lemmon A.R., Lemmon E.M, Takiya D.M., Evangelista O., Walden K.K.O., Grady P.G.S. \& Johnson K.P. 2017. Anchored hybrid enrichment-based phylogenomics of leafhoppers and treehoppers (Hemiptera: Cicadomorpha: Membracoidea). Insect Systematics and Diversity 1 (1): 57-72. https://doi.org/10.1093/isd/ixx003

Gonçalves C.C. \& Mejdalani G. 2017. Three new species of Peruvian Nelidina (Hemiptera: Cicadellidae: Neocoelidiinae) with key to males. Zootaxa 4365 (1): 85-93. https://doi.org/10.11646/zootaxa.4365.1.6

Hamilton K.G.A. 1981. Morphology and evolution of the rhynchotan head (Insecta: Hemiptera, Homoptera). Canadian Entomologist 113 (11): 953-974. https://doi.org/10.4039/Ent113953-11

Hill B.G. 1970. Comparative Morphological Study of Selected Higher Categories of Leafhoppers (Homoptera: Cicadellidae). PhD thesis, North Carolina State University, Raleigh, USA.

Knull D.J. 1942. The genus Neocoelidia in the United States (Homoptera: Cicadellidae). American Midland Naturalist 28 (3): 680-692. https://doi.org/10.2307/2420898

Kramer J.P. 1964. A generic revision of the leafhopper subfamily Neocoelidiinae. (Homoptera: Cicadellidae). Proceedings of the United States National Museum 115 (3484): 259-287. https://doi.org/10.5479/si.00963801.115-3484.259

Kramer J.P. 1967. New neotropical Neocoelidiinae with keys to the species of Coelidiana, Xenocoelidiana, and Nelidina (Homoptera:Cicadellidae). Proceedings of the Entomological Society of Washington 69 (1): 31-46.

Maes P.J.M. \& Godoy C. 1993. Catalogo de los Cicadellidae (Homoptera) de Nicarágua. Revista Nicaraguense de Entomologia 24: 5-34.

Marques-Costa A.P. \& Cavichioli R.R. 2012. Cladistic analysis of Neocoelidiinae (Hemiptera: Cicadellidae) with description of a new tribe. Zootaxa 3483: 1-28.

https://doi.org/10.11646/zootaxa.3483.1.1

Mejdalani G. 1993. Morfologia da cabeça de Versigonalia ruficauda (Walker, 1851), com notas sobre a terminologia (Homoptera, Cicadellidae, Cicadellinae). Revista Brasileira de Entomologia 37 (2): 279-288.

Mejdalani G. 1998. Morfologia externa dos Cicadellinae (Homoptera, Cicadellidae): comparação entre Versigonalia ruficauda (Walker) (Cicadellini) e Tretogonia cribrata Melichar (Proconiini), com notas sobre outras espécies e análise da terminologia. Revista Brasileira de Zoologia 15 (2): 451-544. https://doi.org/10.1590/S0101-81751998000200015

Nielson M.W. \& Knight W.J. 2000. Distributional patterns and possible origin of leafhoppers. (Homoptera, Cicadellidae). Revista Brasileira de Zoologia 17 (1): 81-156.

https://doi.org/10.1590/S0101-81752000000100010

Oman P.W. 1949. The Nearctic leafhoppers (Homoptera: Cicadellidae). A generic classification and check list. Memoirs of the Entomological Society of Washington 3: 1-253.

QGIS.org 2021. QGIS Geographic Information System. QGIS Association. Available from http://www.qgis.org [accessed 24 Feb. 2021].

Rakitov R.A. 1997. On differentiation of cicadellid leg chaetotaxy (Homoptera: Auchenorrhyncha: Membracoidea). Russian Entomological Journal 6: 7-27.

Young D.A. 1968. Taxonomic study of the Cicadellinae (Homoptera: Cicadellidae), Part 1, Proconiini. Bulletin of the United States National Museum 261: 1-287. https://doi.org/10.5962/bhl.part.20869 
Young D.A. 1977. Taxonomic study of the Cicadellinae (Homoptera: Cicadellidae). Part 2. New World Cicadellini and the genus Cicadella. Bulletin of North Carolina Agricultural Experiment Station 239: $1-1135$.

Zanol K.M.R. 1988. Morfologia de Neophlepsius gracilis (Osborn, 1923) (Homoptera, Cicadellidae, Deltocephalinae). Revista Brasileira de Entomologia 32 (1): 69-93.

Manuscript received: 4 April 2021

Manuscript accepted: 27 August 2021

Published on: 18 October 2021

Topic editor: Nesrine Akkari

Section editor: Christopher Dietrich

Desk editor: Eva-Maria Levermann

Printed versions of all papers are also deposited in the libraries of the institutes that are members of the EJT consortium: Muséum national d'histoire naturelle, Paris, France; Meise Botanic Garden, Belgium; Royal Museum for Central Africa, Tervuren, Belgium; Royal Belgian Institute of Natural Sciences, Brussels, Belgium; Natural History Museum of Denmark, Copenhagen, Denmark; Naturalis Biodiversity Center, Leiden, the Netherlands; Museo Nacional de Ciencias Naturales-CSIC, Madrid, Spain; Real Jardín Botánico de Madrid CSIC, Spain; Zoological Research Museum Alexander Koenig, Bonn, Germany; National Museum, Prague, Czech Republic. 